Article

\title{
Humanizing the It: Martin Buber on Technology and the Ethics of Things $\S$
}

\author{
Asher D. Biemann
}

check for updates

Citation: Biemann, Asher D. 2022. Humanizing the It: Martin Buber on Technology and the Ethics of Things. Religions 13: 137. https://doi.org/ 10.3390/rel13020137

Academic Editors: Claudia Welz, Christian Wiese and Bjarke Mørkøre Stigel Hansen

Received: 16 December 2021

Accepted: 29 January 2022

Published: 2 February 2022

Publisher's Note: MDPI stays neutral with regard to jurisdictional claims in published maps and institutional affiliations.

Copyright: (C) 2022 by the author. Licensee MDPI, Basel, Switzerland. This article is an open access article distributed under the terms and conditions of the Creative Commons Attribution (CC BY) license (https:// creativecommons.org/licenses/by/ $4.0 /)$.
Department of Religious Studies, University of Virginia, Charlottesville, VA 400126, USA; ab5j@virginia.edu $\S$ This essay is dedicated to Paul Mendes-Flohr, who has been an unparalleled teacher, mentor, and friend to many of us. There is no better theme to honor Paul's legacy than the theme of Menschlichkeit.

\begin{abstract}
Martin Buber's writings on technology are scarce and seemingly subordinated to what

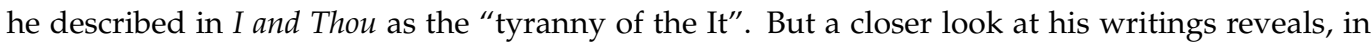
fact, a life-long reflection on the dialogical potentiality of things-whether artworks, buildings, or machines - that echoed broader discourses on technology at the time. Beginning with Julius Goldstein's Die Technik (1912), which Buber edited for his series Die Gesellschaft, and concluding with Buber's reception and critique of Heidegger, especially during the 1950s, we can see that Buber critically engaged with the question of technology with respect to labor and community, art and artisanship, and the ethics of thinghood. The essay contextualizes Buber's repeated call to "humanize technology" in early 20th-century debates on technology and in the post-1945 crisis of humanism. What it argues is that Buber framed technology not only through its aesthetic potential, as Werk, but also as another form of solidarity and care without which community and respect for our environment would not be possible.
\end{abstract}

Keywords: Martin Buber; Martin Heidegger; technology; machine; ethics of things; dialogue; I-It; Hasidism; labor; community and society

\section{A Dispirited Kibbutz}

In April 1961, at the age of 83, Martin Buber hosted a series of conversations with Kibbutz members at his Jerusalem home. Questions of work, labor, and production emerged repeatedly, and the fact that farming machines had begun to replace the intimate interaction with nature seemed of great concern to some leaders in the cooperative. "Work is no longer physical", one member lamented, "and our immediate contact with nature and animals has been lost. Our only contact happens through the machine". ${ }^{1}$ The supposedly uplifting value of toiling in nature, the liberating, even self-redemptive, aspects of work which A. D. Gordon, the pioneer of Labor Zionism, had celebrated half a century earlier, seemed displaced by the technological revolution and the urgent need for production during the first decades of the modern Jewish state. ${ }^{2}$ For the members of the Kibbutz the proliferation of everyday technology meant the loss not only of their founding ideals but also of the basic relationship between worker and work. And it would only have been natural to expect a sympathetic ear from Buber, who had written so eloquently over the course of a long life against the reduction of the interpersonal world to a thing, or to a soulless "It". But Buber took a surprisingly pragmatic, down-to-earth approach: Presenting himself as a "realist", who knew nothing of "ideas" but only of "concrete, real things", he insisted that one must not renounce the achievements of technical engineering. What was needed was not the demonization, but the "humanization of technology". In fact, it was precisely within technology, he suggested, "that true interhuman relations would occur". (Buber 1985, p. 310). To illustrate his point, Buber recalled a longer conversation with the Indian philosopher Rabindranath Tagore, who had once encouraged the modern Jews to "discard all their machines and canons into the sea" and to resist the "soulless 
technology of the Occidental nations". Like Tagore, Buber considered the Jews an "Oriental" people. But unlike the Indian philosopher, he refused to condemn "Western" technology, comparing it instead to a "ponderous symbol" we are destined to carry on our backs: "We cannot throw it off, and our difficult task and responsibility remains to carry the human and humane values into technology itself". ${ }^{3}$

To the disheartened members of the Kibbutz, Buber's answer may not have offered much relief and appeared, perhaps, as an ideal too lofty and removed from the real world of manual labor and unstoppable industrialization. But as a philosopher, who claimed to know nothing of ideal worlds and always insisted on the rooted reality of his thought, Buber traveled along a "narrow rocky ridge", as he often put it, that refused itself to clearcut moral distinctions and conceptual dichotomies. Neither his signature duality of the basic words I-You and I-It, which informed his dialogical philosophy since the publication of $I$ and Thou in 1923, nor the quotidian distinction of good and evil, nor, for that matter, the classical polarity of theory and practice represented, for Buber, true opposites or, as we would say in today's computational jargon, "binaries" of thought. Against all moral "Manicheism" and ethical principledness Buber repeatedly postulated a "holy insecurity", a state of paradox and perplexity that could answer only to the unique and unforeseeable demands of the moment. ${ }^{4}$ “The situations have a word to speak!" Buber wrote in 1963. "And the real, the biographically or historically real, situations are not simple and plain like principles; they bear the contradiction in themselves, they lift it to our faces, and we may not ignore it, for the reality stands in contradiction". 5

Such sense of contradiction or, as one could argue, constructive ambivalence, also shaped Buber's understanding of technology. Very little has been written on this subject by comparison, at least, to the rapidly growing field of philosophical ecology and environmental thought which has been able to draw on Buber's Hasidic writings and his accounts of dialogical intimacy with horses, cats, and several species of trees, and which appears to be far more becoming to our contemporary yearning for "You-ness" than the cold world of inanimate things and machines. ${ }^{6}$ Indeed, Buber never developed a robust theory of technics and technology, let alone a theory of the kind of trans/post-humanist turn that has defined, with good reason, the most recent decades of discourses on cybernetics, artificial intelligence, and the regime of information. ${ }^{7}$ If we can locate in Buber's oeuvre reflections on the thing-world and on the role of technology in modern society, then they remain scattered instances frequently attached to what Buber, in I and Thou, called the "tyranny of the proliferating It", or to what, in 1945, he characterized as the "great crisis". "The world of machines", he wrote then, "which once was intended by its inventors to be a faithful slave to our communal will, exhibits today, as it is driven by an anti-communal will, the same satanic autonomy as the magic broom in the Sorcerer's Apprentice". ${ }^{8}$ Yet, as his response to the Kibbutz members suggests, Buber thought of technology not only as a necessary "evil", but as something that could indeed be "humanized", as an actual space in which human relationships could manifest themselves. Did Buber, then, envision the possibility of genuine dialogue not only with horses and trees, but also with thing-works and machines? And what would the implications be of such a "dialogue"?

The following essay is an attempt to reconstruct Buber's understanding of technology from the few references we find present throughout his work. Let it be clear that the understanding of technology at this time was still predominantly "analogue" and would at best elicit a nostalgic smile from our present generation. ${ }^{9}$ The spirit of this essay, therefore, can only be strictly historical, and it is left to the reader to judge its relevance for our day. What I will argue is that Buber's writings reflect a life-long occupation with the dialogical potentiality of things-whether artworks, tools, or machines-that echoed broader discourses on technology at his time while resisting the popular sentiment of techno-pessimism as well as the mythic glorification of technology during the interwar period which would become a hallmark of what Jeffrey Herf has termed "reactionary modernism". ${ }^{10}$ More specifically, I will suggest that Buber's references to technology did not function as a mere rhetorical counterpoint to an idealized, let alone supreme, world of dialogue but, in fact, constituted 
his own rudimentary thinking about things, which anticipated and, in later years, resembled Martin Heidegger's post-war reflections on technology and technical thinghood. ${ }^{11}$

To develop my argument, I will ask the reader to navigate with me two parallel contexts: First, the intellectual historical context of technology debates before and immediately after 1945. Second, the conceptual context of Buber's philosophy of dialogue as a systematic Leitmotiv connecting his earlier philosophy of religion and his later philosophical anthropology, which encompassed also his social and political thought and, however fragmentary, his aesthetics. The question of technology remained largely unarticulated in these dialogical works. But every so often it became an explicit instance of Buber's phenomenologyand anthropology—of the "It-World" which, in his youthful Daniel (1913), he called the "world of orientation", and which, in I and Thou, manifested itself as the world of causality (Ursächlichkeit) and experience (Erfahrung): "Man goes over the surfaces of things and experiences them. He brings back from them some knowledge of their condition-an experience. He experiences what there is to things". ${ }^{12}$ That epistemic world of It, however, still remained tethered to Buber's insistence on the redeemability, on the "hallowing" of the mundane, which emerged as a prominent theme and critique of secular modernity, especially in his Hasidic writings. Hasidic "pansacramentalism", as Buber put it in an essay of 1935, should be viewed as a response to the crisis ushered in by the separation of sacred and fundamentally "non-holy" spheres, by the expansion of the "a-sacramental" or, put differently, by the process of secularization itself. Not that Hasidic pansacramentalism perceived the world enchanted. "The man of sacramental existence", writes Buber, "is no magician ... , he exercises no power but a service, the service".${ }^{13}$ Hasidic pansacramentalism was no act of romantic re-enchantment, for Buber, but an act of care for an irrevocably disenchanted world.

Accordingly, Buber understood service, Avodah, or work, or prayer, as an act of resacralization, an elution of "holy sparks" from their material shells that required a total "giving of oneself", an undivided devotion to a world in need of repair. But repair, to Buber, was not merely "fixing", as in today's threadbare mantra of Tikkun Olam. Rather, it required the ennoblement of the everyday and its everyday objects and events. "Around each man", Buber writes in the introduction to his Baal-Shem, "... is laid a natural circle of things which, before all, he is called to set free ... his animals and his walls, his gardens and his meadow, his tools and his food. In so far as he cultivates and enjoys them in holiness, he frees their souls". And it is for this reason, as Buber quotes from the Baal-Shem, that "a man should always have mercy on his tools and all his possessions". ${ }^{14}$

If we succeed in reconstructing a fragmentary theory of technology from Buber's system of thought, then it will need to rest on his fundamental premise that the material world, even the inanimate world of artifacts and things, is not beyond the dialogical. It will need to acknowledge that a thing, no matter how mundane, possesses a dignity of its own, and that ethics, having finally expanded the spheres of compassion and rights from the human person to animals and nature, cannot, therefore, ignore the "rights" of things. Thus, our task cannot only be historical. It must also gesture towards what the late Vilém Flusser, in his phenomenology of Things and Non-Things, called the "de-vulgarization (perhaps sacralization?) of the vulgar". ${ }^{15}$

\section{Herzl's Faith in Machines}

But let us first return to the historical context. Martin Buber's 1961 conversations with the Kibbutz members from Yotvata, Ein Gedi, and Afikim echoed an earlier reflection on technology he had published in the liberal Israeli newspaper Ha'aretz in May 1940 occasioned by what would have been Theodor Herzl's 80ieth birthday. The essay "If Herzl Were Still Alive" was an effort to imagine how the author of The Jewish State would have perceived progress in the Yishuv. For Buber, who viewed himself as a religious liberal, it was an occasion to contrast Herzl's political liberalism with the necessarily "non-liberal idea" of a Jewish State. 16 "States can grow and flourish in liberal hands", writes Buber, "but no state, to my knowledge, has ever been founded on liberal intentions" ${ }^{17}$ Unbeknownst 
to its founder, the very idea of a Jewish polity could not be fully harmonized with the ideals of liberalism which, by definition, included ideals of universalism, individualism, and uninhibited progress, but not the principal idea of return and national rebirth. This, for Buber, was the inner contradiction of political Zionism and, perhaps, its tragedy. Oblivious to that contradiction, Herzl held fast to the liberal illusion of progress falling prey, thereby, to another illusion of his time: "He believed in technology ... And this faith in technology would also rule his Zionism". ${ }^{18}$ Technology was the "magic" of his age, and with every technological advancement Herzl believed the Zionist movement had come a step closer to national rebirth, to the "delightful renaissance" he had predicted in The Jewish State. ${ }^{19}$ But this liberal confidence, Buber insisted, did not come to fruition: "The formation of the social question did not advance, or only seemingly advance, with the development of technical means, and one may suspect that every technological progress to follow will only complicate the social question and make its solution increasingly difficult". (Buber 2019c, p. 40). The "apparatus of life" (Lebensapparat) had devoured the substance of life (Lebenssubstanz). The "making" of things had buried the "true" sources of our humanity. "Human life", writes Buber, "begins only where the certainty of making ends and where we become attentive to what cannot be made". (Buber 2019c, p. 40).

Jürgen Habermas would later call attention to the fundamental difference of the "grown" and the "made", between what is manufactured and what has come to be by nature.$^{20}$ For Habermas, the challenge of modern technology—of biotechnology and eugenics, to be precise-consists in the increasing dedifferentiation of nature and the manufactured, a challenge neither Herzl nor Buber could have experienced with the same urgency. ${ }^{21}$ Yet Buber was keenly aware that the "certainty of making", upon which all faith on technology must rest, belonged to a different order than the unreliable, unpredictable, unsurveyable world of what cannot be made, nor utilized, but that can only be "received". In I and Thou, Buber calls this world a world that "lacks density, for everything in it permeates everything else", and one that "lacks duration, for it comes even when not called and vanishes when you cling to it". ${ }^{22}$ This world, of course, is the world of "You-moments", of "queer lyric-dramatic episodes", uncanny, unstructured, and "shaking up our security". (Buber 1995, p. 84). It is a world starkly opposed to the world of continuity and planned objectives. But it is the world-the only world, in fact-allowing us to become truly human. "Man becomes an I through a You", was Buber's famous formula, and it implied that without a You the individual lacks the decisive force of selfhood: The power of being transformed, of becoming another, or as he wrote in Daniel: "Transformed he carries out with the movement of his being the secret movement of the world". (Buber 2001, p. 229; Cf. also Buber 1995, p. 80). The purpose of the state, by contrast, much like the purpose of technology itself, is to eradicate the risk of instability and transformation. States, like machines, seek permanence and perpetuity.

Had Herzl been alive today, Buber writes, he would surely have recognized that modern technology with its promise of perfection and stability had lost sight of the purpose and "becoming" of man. He would have recognized that being human can only be an infinite "task" and that the regeneration of a people, the creation of true community, cannot be planned and engineered, as Herzl's utopian novel Altneuland (1902) had envisioned, but only grow through the awakening of the "spirit": "Spirit is not something that can be made, nor something that simply exists. It must be called upon, and what is more, it must be called to life". (Buber 2019c, p. 41). If Herzl had come to this realization, his "Zionist soul", as Buber firmly believes, would have finally "defeated his inner liberalism". ${ }^{23}$

\section{Mechanical Society and Organic Community}

Buber's critique of Herzl's liberalism engaged several well-known tropes of early twentieth-century Kulturkritik: $:^{24}$ It implicitly aligned the state with a mechanistic apparatus of stability frequently described in his work as Getriebe (literally gearbox, but also that which drives us); it viewed the faith in technology as a fault of liberalism; and it sharply distinguished between organically "grown" communities and artificially "made" societies. 
Indeed, as Paul Mendes-Flohr has shown in his magisterial study from Mysticism to Dialogue, Buber embraced already in his earliest writings the concept of community (Gemeinschaft) so favored by fin-de-siècle intellectuals as a critique of civilization and organized society (Gesellschaft). ${ }^{25}$ Thus, in a lecture delivered in June 1900 at the Neue Gemeinschaft circle that had formed around the slightly dubious brothers Heinrich and Julius Hart in Berlin, Buber passionately identified community with inner vitality, whereas society appeared to him as an external form of association: "Only when the cheerful rhythm of life will have triumphed over rules, only when instead of dead conventions the eternally flowing, eternally transforming inner law of life will come to power, only then will humanity be free from the dictates of emptiness and untruth". ${ }^{26}$ The "new community", Buber announced, would liberate us from the "yoke of utility", from society's Nutzgetriebe, and from the "throngs of the city" to return to "virginal soil" and to the "free love of grown nature". In a later essay, Buber explicitly referenced Ferdinand Tönnies' influential treatise on Community and Society (1887) to contrast the "organic togetherness" of community with the "mechanical type" and "ordered separateness" of society. ${ }^{27}$ Like Tönnies, Buber lamented the decline of small communal orders, such as village or church communities, into "state-like machineries" and complex societies of mere functionality: "Society today is an organism of dying cells, a frightening fact that is obscured by the reliable functioning of a pseudo-organic mechanism created from high-performance parts, called the state". ${ }^{28}$ And like Tönnies, Buber saw no immediate way to return to the innocence of authentic communal life. No constituted state, not even a socialist one, could recreate that bygone past. "To be sure", writes Buber, "we cannot go back behind mechanized society". But he also believed that "we can go beyond it, towards a new organic one". ${ }^{29}$

Where Tönnies had seen "scattered seeds" of communal spirit that would germinate underground to break forth in the future, Buber found holy sparks of community engendered in Hasidic teaching, sparks that could be harnessed to revive not only local communities but, ultimately, the "community of humankind" altogether or, as Gustav Landauer had written, the "oldest and most universal community: the community with humanity and with the universe". (Buber 2019b, p. 169; Also Landauer 1901, p. 48). Here, Buber differed from Tönnies, whose vision of the "common man" was a strictly "secular" and economic one that did not yet have to grapple with the trauma of the Great War. But he shared with Tönnies a deep distrust in "manufactured", rather than "created" associations. "[W]e speak of mechanical work ... referring to forging plans, machinations, weaving intrigues, or fabrications", wrote Tönnies, "which are directed to bringing forth the means ... to our desired ends". ${ }^{30}$ Applied to society, these purpose-oriented and fraudulent means, as Tönnies feared, would also affect human feeling and thinking. Technology, thus, was not only a symptom of modern society. It had also become a way of being.

Distrust in "mechanical" societies and the world of technology at large was, of course, no novel sentiment in Tönnies' times. The metaphoric distinction between "organic" and "mechanical" societies and the polemic against the state as a "political machine" (Hobbes) had been a common trope since at least Rousseau. ${ }^{31}$ In the German tradition, the machine metaphor was especially popularized by J. G. Herder, who favored states constituted by culture and education to those founded upon "mechanical statecraft". Accordingly, despotism, for Herder, would turn men into machines. ${ }^{32}$ Likewise, J. G. Fichte, who had a profound influence on Jewish thinkers as disparate as Hermann Cohen and the early Zionists, derided the state as "societal machine-craft" in which "all lifeless things were conjoined", calling it a "merely mechanical institution", or an "idle work of gears". ${ }^{33}$ Eduard Gans, the leading liberal interpreter of Hegel's political thought who, in 1827, predicted that the monarchic traditions would soon be "dead" (erstorben) and Europe governed according to the American Constitution, warned that the state should neither be a "mechanism" nor a "mechanical work of art". ${ }^{34}$ In 1849, Thoreau, who found much admiration in Buber, spoke of the "machinery of society". ${ }^{35}$ The German-American philosopher Ernst Kapp concluded his pioneering Philosophy of Technology of 1877 with a warning against a solely mechanical 
state: "The state, no matter how imperfect or perfect, remains an organism and can never be a machine". ${ }^{36}$ And, writing in 1911, the Jewish publicist Nathan Birnbaum, whose spiritual journey led him from radical secularism to Jewish Orthodoxy, expanded this critique to the "mechanical nationalism" of the political Zionists: "I have long come past the sin of my youth, which was the mechanistic idea of territory and statehood". (Birnbaum 1913, p. 241). By the time, then, that Buber launched his campaign against "mechanized society", this notion had been a long-standing concern, if not established itself as a ubiquitous cliché.

\section{Weimar Machine-Wreckers}

As to be expected, the correlation between state and machine went in tandem with a critique of technology itself. While the age of rationalism frequently turned to automatons and well-tempered machines to explain the human body and the universe-think of Leibniz's clockwork-creator or Julien Offray de la Mettrie's L'homme machine-the early nineteenth century became increasingly disenchanted with the effects of scientism on everyday life and commerce. Goethe's Wilhelm Meister, for instance, already included dark reflections on the advancement of the technological age. "The rampant rise of machinelife tortures and frightens me", says the owner of a spinning mill. "It rolls towards us like thunder, slowly, slowly, yet with sure direction: It will come, and it will hit us". ${ }^{37}$ This notwithstanding, Victorian confidence in the redemptive power of machines seemed unassailable when Thomas Baker, in 1845, published his ode to The Steam Engine, whose ninth canto sported a "Vision of the World Regenerated by the Gospel and the Power of Steam" and the "Great Messiah's reign": "The chariots here, in gorgeous train, /Sped swift in pageant tours; / And vessels on the rolling main/Moved by these Mighty Powers". ${ }^{38}$ Matthew Arnold, on the other hand, writing in 1869, called the same "faith in machinery" our "besetting danger", for it forced human culture to be modeled in a mechanistic image. ${ }^{39}$ By 1872, when Samuel Butler published his satirically dystopian novel Erewhon, the faith in the gospel of machines had already been profoundly shattered: "How many men at this hour are living in a state of bondage to the machines? How many spend their whole lives, from the cradle to the grave, in tending them by night and day? Is it not plain that the machines are gaining ground upon us, when we reflect on the increasing number of those who are bound down to them as slaves, and of those who devote their whole souls to the advancement of the mechanical kingdom?" (Butler 1880, chp. 24, p. 200). In 1909, E. M. Forster published another dark satire, "The Machine Stops", in which a giant, globally wired machine-omnipotent and seemingly perpetual-gradually forces humanity into dependence and complacency. When it finally stops on its own accord, a great repair is needed. "But humanity", writes Forster with uncanny foresight, "in its desire for comfort, had over-reached itself. It had exploited the riches of nature too far. Quietly and complacently, it was sinking into decadence, and Progress had come to mean the Progress of the Machine". (Forster 2009, p. 31).

Decadence was a common and problematic sentiment among fin-de-siècle intellectuals, especially those under the spell of Nietzsche, including the young Buber himself. ${ }^{40}$ But it was during the final gasps of World War I, which sometimes came to be perceived as a "war of engineers", that decadence, decline, and crisis led to unprecedented cultural pessimism. ${ }^{41}$ Castigating the ailing Western culture of disenchantment (Vernüchterung) the educator and philosopher Theodor Lessing called for resistance to the "relentless machine of culture" and deplored the "mechanical socialization" (mechanische Vergesellschaftung) of communities: "We are no culture, we serve it ... The machine has grown above our heads". ${ }^{42}$ Ernst Toller, the left-leaning playwright and participant in the short-lived Bavarian Soviet Republic of 1919, wrote a play by the title of Machine-Wreckers-Die Maschinenstürmer (1922) that opens with the ratification of a bill against the assault on machines and ends with workers going to war against their factory equipment: "To war against the tyrant Steam! Destroy the Machine!" (Toller 1922, p. 40). Ludwig Klages, a German philosopher and psychologist of rather right-leaning persuasion, deplored the "self-dissolution of humanity" with men becoming "machine-like" "slaves of their professions" and "murderous technology" 
being the product of "Judeo-Christian morality". ${ }^{43}$ And in Oswald Spengler's notorious and widely popular Decline of the West (1918-22), a chapter on "The Machine" marks the final act of this monument to pessimism, which at once shaped and mirrored the spirit of the time. "The machine", writes Spengler, "works and forces man to be its collaborator". Thus, he continues in a tone by now familiar, the worker and the entrepreneur are "both slaves, not masters, of the machine, which now fully unfolds its nefarious power". (Spengler 1980, pp. 1188, 1191). Less than a decade later, Spengler, returned to the "fate of machine-technology" and what he called the "fifth act" of the human tragedy: "Creation rises against its creator ... the master of the universe is rendered slave to the machine. It forces him, it forces all of us without exception, whether or not we know it, into the path of its purpose. The toppled victor is dragged to death by a furious chariot" ${ }^{\prime \prime}{ }^{4}$

What these few examples illustrate is the gradual emergence of an intellectual tradition with fixed tropes over the course of but a century that has lost little of its original appeal in many circles of our day. What it also illustrates, however, is the political and ideological adaptability of techno-pessimism: It could come from the far left or the far right, or from anywhere in between. It spoke to reactionaries, spiritualists, humanists, anarchists. And it created a vocabulary that could be resumed, almost seamlessly, in post-1945 discourses on the atomic and "technotronic" age, which involved virtually every philosopher of name, including Martin Heidegger, Karl Jaspers, Jacques Ellul, and the once widely revered Lewis Mumford, who coined the language not only of the "new megamachine" but also of the "megatechnic wasteland". ${ }^{45}$

\section{In Defense of a Mechanized World}

For every instance of verbal "machine-wrecking" there existed, of course, outspoken defenders of technology and progress. Richard Coudenhove-Kalergi's Apologie der Technik of 1922 can be seen as a direct response to authors such as Theodor Lessing or Ludwig Klages, both of whom, like numerous intellectuals at the time, including, once again, Buber himself, believed that Europe's salvation would come not from within but from a non-technologized, unadulterated East. Building upon a more optimistic view of technology that could be found in Marx, the controversial utopist Edward Bellamy, the no less controversial Viennese inventor and social reformer Joseph Popper-Lynkeus or, as we have seen, Theodor Herzl (whom he greatly admired), Coudenhove-Kalergi promoted Europe's "technological world mission" as a distinct form of liberation and radical liberalism: "Europe is a function of technology", he declares, and it was "technology that awakened Europe from its Asian sleeping-beauty slumber of the Middle Ages". (Coudenhove-Kalergi 1922, pp. 22-23). In fact, Coudenhove-Kalergi, who was born to a Japanese mother and an Austro-Hungarian diplomat in Tokyo and was raised in a Buddhist-Catholic household, warned against Asia's "mysticism" and "passivism" threatening Europe's "masculine activism", "heroism", and "rationalism": "Buddhism would choke technology — and with it the spirit of Europe". ${ }^{46}$ The "neo-Buddhists" of his time, Coudenhove-Kalergi accused of "cultural treason" (Kulturfrevel) and "cultural suicide". Technology itself he celebrated as the liberator of the working classes and the poor, as well as the emancipator of women. ${ }^{47}$ "The machine", he writes, "is the liberator of man from the yoke of slavery". (Coudenhove-Kalergi 1922, p. 39). Its cultural goal (Kulturziel) is to free us from bondage and to afford equity to all by equally distributing wealth, power and leisure: "Not proletarization of humanity, but aristocratization!" exclaims the scion of an old aristocratic family (Coudenhove-Kalergi 1922, p. 43).

Coudenhove-Kalergi's little known manifesto on technology must be viewed in the context of his life-long efforts to combat sentimental nationalism and establish a panEuropean union based on reason, law, and "technological heroism". In his apologia, he not only defended technology as a democratizing tool-much like social media today is occasionally, and perhaps naively, credited with enabling the globalization of democracybut also as the overcoming of state and labor. No other revolution than ethics and technology would obviate the "tyranny of the state" and the "tyranny of labor". Just as the mission 
of the state should be to make itself "superfluous" and be fulfilled in "cultural anarchy" (Kulturanarchie), so the mission of labor is to make itself superfluous and enable, through technology, a universal state of "cultural leisure" (Kulturmuße) (Coudenhove-Kalergi 1922, pp. 12-13). The mechanization of the state, then, would lead to its eventual self-negation.

Others, such as Walther Rathenau, who was trained an engineer before becoming Foreign Minister of the Weimar Republic, were less radical in their defense of technology but still believed in the salutary function of science. Rathenau's Mechanik des Geistes (1913) and his earlier Kritik der Zeit (1912), which included a long and level-headed discussion of the "mechanization of the world", promoted a rational society unencumbered by the powers of religious superstition and the same political frenzy that would, ultimately, lead to his assassination in 1922. ${ }^{48}$ In 1924, the sociologist Helmuth Plessner, an early proponent of philosophical anthropology, a discipline later adopted by Martin Buber, published a short essay on "Utopia in the Machine", in which he criticized both, the naïve faith in progress and the romantic yearning for Gemeinschaft that had produced the very antimodern Dekadenzphilosophie associated with Spengler. The answer, for Plessner, was not the "grandiose destruction of machines" but the development of "qualitatively higher types of machines" that would liberate more and more people from the ills of manual labor while giving others a dignified environment to operate them. Like Coudenhove-Kalergi, whose work he approvingly cites, Plessner expects a "self-negation" of the factory through the "evolution of the apparatuses". In the end, he foresees the "beginning of an age of planetary solidarity supported by the logic of machines". ${ }^{49}$

\section{Technology as Continuation of Creation}

The perhaps best known defense of technology at the time came from Friedrich Dessauer, a pioneer of X-ray technology and leading Technikphilosoph at the University of Frankfurt. In 1927 Dessauer published Philosophie der Technik in an effort to reconcile the opposing sides of the debate and to offer a balanced understanding of technology itself. A deeply religious (Catholic) man, who was forced into temporary exile by the Nazi regime on account of his Jewish descent and political opposition, Dessauer viewed the processes of inventing, engineering, and making as participation in, and augmentation of, divine creation: "It is a momentous destiny to be actively participating in creation, in such a manner that the things we create continue to work with unimaginable autonomy in the visible world". (Dessauer 1928, p. 66). Technology, thus, was not the displacement of creation, as its critics often feared, but its continuation-Weiterschöpfung — and Dessauer went as far as to consider technology "an encounter with God": "Through the work of technology the spirit of creation enters our age, which is the tomorrow of humanity". (Dessauer 1928, p. 68). As such, however, the human activity of technical engineering and the works it produced were both endowed with the same ethical responsibilities and inherent rights all works of creation share. Like the work of art, the product of engineering "faces its author as an autonomous work". But unlike the work of art which, once created, exists in its own sphere, the work of engineering continues to work (wirken) among its contemporaries (Mitwelt) and into the world of their descendants (Nachwelt) who continue to use it. By the same token, argues Dessauer, technical things, like all works of creation, point back to their creator: "A breeze of humanity meets their beholder - technical engineers and laborers have expended their lives to create them for me, for the fellow human being, to maintain and elevate my life, to save me, to give me happiness". (Dessauer 1928, p. 26). The work itself belongs to what Dessauer calls the Fourth Realm, the realm of the Dingan-sich, which Kant had surmised, but not yet discovered. It belongs to the "second world of things", to a "Metakosmos" which, unlike the natural world we live in, is intimately familiar to us. I cannot arrive at the Ding-an-sich of a tree; but I can, Dessauer believes, arrive at the Ding-an-sich of an engineered object, of a machine, because I will recognize in it not only the potential of my own imagination, but also my own, shared humanity. ${ }^{50}$

That inventors and engineers were no villains but "servants" to humanity was of existential significance to Dessauer, whose long research on the medical applications of 
X-rays had left him grossly disfigured and ailing with cancer. That technology came with cosmic responsibility was equally apparent to him, and it was for this reason that he insisted inventors and engineers should be public figures in a public discourse. Thus, in 1927, Dessauer already spoke of the dire need for clean energy, as we understand it today. Likewise, he was well aware of the fateful opposition between technology's aspired humanitarianism and economy's inherent "egotism", between the work of science and the product of the marketplace, between actual need and imagined demand. And finally, he set out to rehabilitate the "thing" itself-whether tool, machine, or any other object of use. A thing, for Dessauer, was never a merely a thing, no matter how mundane, but a work ultimately made by human hands and reflecting the humanity of its maker.

Things and artifacts, then, belong to the realm of culture, which Ernst Cassirer would later define as "cooperative doing" (gemeinsames Tun) and therefore command our respect for their inventors and crafters. ${ }^{51}$ Thus, Cassirer, whose entire philosophical system was dedicated to the inseparability of culture's realms, described the spiritual task of technology as "resisting the mere fatality of things and their effects". ${ }^{52}$ An object (Gegenstand) is always a thing to know (Erkennen) and, at the same time, a thing to acknowledge (An-Erkennen). ${ }^{53}$ It may be used as a tool that can always be abandoned to the realm of letting-be (StehenLassen). But when we treat it as a work, then a sense of presence and solidarity emerges. "This feeling of solidarity", writes Cassirer, "distinguishes the true artisan: The specific, individual work that emerges from his hands no longer appears as a thing to him, but he recognizes in it himself and his own, most personal deed". (Cassirer 1985, pp. 59, 76). The artisan, like the engineer, can say to his or her work: "I have found you". (Cassirer 1985, p. 82; Dessauer 1928, p. 42). Here, for Cassirer, lay the origin of "another kingdom of ends", for the "ethicization of technology" and the recognition that machines and things cannot have a purpose of their own, that any work, therefore, must be derived from, and point towards, the "ethico-teleology" of the human being. Here emerges, for Cassirer, a new "solidarity of labor" and a new Schicksalsgemeinschaft, "a community of fate connecting all those who are active on its work". ${ }^{44}$ And here, finally, we are prepared to return to the philosophy of Martin Buber.

\section{Technology and Die Gesellschaft}

There is little evidence that Buber engaged in earnest with any of the authors cited above. But he did recognize that the question of technology, which would be asked again in 1954 by Martin Heidegger, was a question not only about science but of culture and society. Thus, Buber solicited a volume on Die Technik for his acclaimed series of "social-psychological" monographs Die Gesellschaft, which he edited between 1906 and 1912 (See Mendes-Flohr 1978, pp. 111-30). Die Technik was, in fact, the final volume to appear in 1912 before the series faltered. Its author was the Darmstadt based physicist and philosopher Julius Goldstein, editor of the German Jewish bimonthly Der Morgen, and a prolific lecturer and writer on Jewish matters as well as on the culture of technology. ${ }^{55}$ Together with his wife, Margarete (Neumann), who was active in the Frauenhilfe and later, after emigrating to England, became a leading figure in liberal Judaism, Goldstein lived as a socially and Jewishly engaged thinker, whose approach to technology was sociological, ethical and, like Dessauer's, deeply religious. In 1909, he published an essay on the "Sociology of Technology"; in 1911, he wrote on technology's ethical problems and on the social rights and duties of the technical engineer (Goldstein 1909, 1911). It was this attention to technology's moral and religious questions and to the technical engineer's role as a "social mediator" (soziales Vermittleramt) that might have inspired Buber to commission Goldstein to contribute a monograph. And it was through Goldstein's monograph that Buber, presumably, became most intimately acquainted with technology as a question of culture and social psychology.

Goldstein's Die Technik anticipated and prepared much of the later literature we have already surveyed. Its moderate critique of technology could at once appreciate the "virtue of Sachlichkeit" (objectivity) and the dangers of "ideal-less realism"; it acknowledged the ad- 
vantages of "self-regulating machines" and alerted to the loss of human responsibility and accountability in the process of automatization; it credited technology with the liberation of women and warned against technology's impact on the "souls of the workers"; and it clearly articulated that economic demand, or the insatiability of product-desire, would send culture into a new state of dependence and that technological progress did not necessarily mean the advancement of human reason. What Goldstein advocated throughout his slim monograph was a conscious correlation between machine culture and human culture: "The advancement of technology requires for its own sustainability an ever greater moral personality". (Goldstein 1912, p. 12). Accordingly, the problem of technology was primarily a problem of education, a Bildungsproblem of the technical engineer. Technical students, he argued, should learn history, ethics, philosophy, and realize that their duty would be not merely to invent but to enable a "social communion" (Gemeingefühl) that would bridge the gap between the working classes and the class of entrepreneurs and industrialists. Ultimately, Goldstein believed, the mechanization of society would transcend its own rationality and unleash new religious forces, leading to an act of collective introspection and an "inner renewal of life". "Thus, the moral question that technical culture poses to us with new urgency pushes towards religion. Not the religion of the mystical gaze, but the religion that will strengthen man in his spiritual abilities, so that he can become master again over the powers he has created". (Goldstein 1912, p. 73).

\section{The Presence of Things}

By the time Goldstein published Die Technik, Buber had already shifted away from his earlier mystical temper still prevalent in his Ecstatic Confessions of 1909. Not that his temper had resembled "new age" mysticism in the first place. Buber, like Fritz Mauthner or Gustav Landauer, who translated the works of Meister Eckhart, turned to mysticism not as a path to self-fulfillment, nor as escapism from worldly misfortune, but as an alternate epistemologyas a critique of language and knowing. ${ }^{56}$ The silence of the mystic appeared to Buber as a skeptical abstinence from positive knowledge, from the possession of Etwas (something), and thus as a "symbolon against the gods and angels of the Getriebe". ${ }^{57}$ The mystic seeks unity, yet language and perception enforce the division of world and I: The Getriebe allows us to "have" things, but it is only through the surrender to a world-thing, through the complete immersion in it, which, in turn, must immerse itself in the surrendering subject, that "unity" can be experienced. (Buber 2012, pp. 50-51). But this unity produces no specific knowledge. In his Daniel, Buber resumed his quest for unity, developing a more nuanced approach to mysticism and offering a poetic epistemology that encompassed the relation to things. "It is as if we violate the meaning of things", muses Daniel in the first dialogue, and we soon learn that the "gates to the One" are opened not above the things, nor in between them, but in every thing that stands before us (Buber 2001, pp. 184, 186).

Buber's Daniel distinguished between realization (Verwirklichung) and orientation as two modes of confronting the world. Orientation belongs to the "security" of knowing; it is a simulacrum of pre-conceived images, a "dead light", an "economy that saves but does not renew". (Buber 2001, p. 196). It belongs to the world of means (Mittelwelt) and to those among us who "do and make things", who only achieve something (Leistende) (Buber 2001, p. 199). Realization, by contrast, is an always renewed risk; it accomplishes nothing and lives far from the world of products and concrete "outcomes" so cherished by us today. It is a form of "deed", but does nothing to the thing it confronts. It accepts, rather, the pure givenness of the other. "Receive the tree with your directed force", exclaims Daniel, "surrender yourself!" 58 In this moment of surrender, which differs from ecstatic self-dissolution and, therefore, abandons the classic idea of unio mystica, the individual becomes a "truly present human being". (Buber 2001, p. 229).

In I and Thou, Buber will elevate presence (Gegenwart) to a way of being that appears, at first blush, diametrically opposed to the world of objects (Gegenstand). But already in his Daniel he rejects the notion that actualization and orientation, Gegenwart and Gegenstand, would correspond to two separate types of humanity. Rather, they exist "side by side" in 
each of us. Buber will later call them our "basic dispositions". ${ }^{59}$ Living in the mode of actualization alone would render us "somnambulants" in the real world, while the mode of orientation awakens us to the "duality of all things". (Cf. Buber 2001, p. 214). All culture, for Buber, must live in this polarity: "There is no I but the I of tension". (Buber 2001, p. 244). But it is the same polarity that allows us to function in the world of things and to honor the practice and works of science and technology as means of orientation, without succumbing to "orientation's supremacy". (Buber 2001, pp. 194, 200). Or in the language of I and Thou: "Without It a human being cannot live. But whoever lives only with that is not human". (Buber 1995, p. 85; German: Buber 2019a, p. 58).

The conceptual characteristics of the It-world which, for Buber, does exist not in and of itself, but is constituted by the basic word I-It, are by now sufficiently known: It is the world of concepts and objects, the world of perception (Wahrnehmung), of security (Sicherheit), of the everlasting (Bestand, not to be confused with the eternal); it belongs to the temporality of the past and to the logic of causality and continuity; it is reliable organization (Einrichtung) in time and space; it is experience (Erfahrung) and utilization (Gebrauchen). It is no "evil" world, as Buber explains in I and Thou, no more than matter itself could be called evil; but it still is a world of "life-long dying" (dauerndes Sterben). ${ }^{60}$ It is the world, then, of necessary fate to which all You must necessarily return. ${ }^{61}$ If left to itself, "untouched and unthawed by the emergence of any You", the It-world will become "alienated into a demon" and the isolated It a "Golem". (Cf. Buber 1995, p. 111; German: Buber 2019a, p. 74).

But just as the It-world is constituted by the I-It disposition, so it can also be reconstituted in another mode of being: "Whatever has thus been changed into It and frozen into a thing among things is still endowed with the meaning and destiny (Bestimmung) to change back ever again (entwandeln)". (Buber 1995, p. 90; German: Buber 2019a, p. 60). "Man has a great desire to come into personal relation with things and to imprint this relation on them", Buber writes in a later text. ${ }^{62}$ While technology makes the thing at once "autonomous" and "available", the human desire to add, for instance, ornament releases it from its purely technical purpose. But when the ornament no longer is accessory to the tool but becomes its own autonomous image-work (Gebild), then the relation between thing and human being has found a new shape of the "between" — the tool has become a work of art. It no longer stands in the past of its use and utility, but in the immediacy of our gaze (Schauen). "The object", we read in I and Thou, "shall be enflamed to become present". ${ }^{6}$

Becoming present was the primary theme of Buber's 1922 lectures on Religion as Presence, where he first articulated his mature dialogical thought. The meaning of religion, for Buber, was nothing less and nothing more than an "absolute present that can never become past and must, therefore, become present and be present at all times and for every time". ${ }^{64}$ At the climactic moment of his lectures, Buber introduces the concept of an "absolute Thou" that cannot be but present and must, therefore, serve as the "inviolable core of a continuous Thou-word". 65 Can one reach this "absolute Thou" by saying "you" to individual things? a listener in the audience wants to know. Can one see in all things a "You"? (Buber 2017, p. 141). Buber cautions his audience that there exists, surely, a difference between the innocent "You" of a child and the intentional "You" breaking through the It-mode of orientation. While the former is undifferentiated and derives from primal connectedness, the latter presents us with a "task" that presupposes a differentiated subject. ${ }^{66}$ It is the task, the imperative of the I seeking presence: "I mean the present, actual human being who says ' $\mathrm{I}$ ' to himself and 'Thou' to another, whether this other is a human being or a part of nature, a being or a thing, a work or a deed". (Buber 2017, p. 127; English: Horwitz 1988, p. 76). At this moment, all thing-like falls away and nothing remains except a "worldlike You". Here, a thing no longer is known, but actualized. "It is the mandate of a thing that strives to come into being". (Buber 2017, p. 97; English: Horwitz 1988, p. 32).

\section{Substantia Rerum and Substantia Humana}

We think, naturally, of the artist who, as Buber puts it, "confronts his work as a Thou, as his Thou, in such a manner that he knows nothing of earlier works that may already 
surround him in the It-world". (Buber 2017, p. 12; English: Horwitz 1988, p. 75). In Man and His Image-Work, which Buber delivered as a lecture in Munich in 1954, it is indeed the artist who is endowed with a unique "gaze" (Werkschau) that contemplates nature as a world of works waiting to be actualized. Whereas the scientist in the "heroic age of physics", which Buber calls the "age of heroic resignation", must orient herself in a world that has now become unimaginable, the artist foresees a secret surplus of meaning in everything confronting us. ${ }^{67}$ In an uncanny (unheimlich), unfamiliar (unheimhaft) world, art comes into being through "elementary renunciation" of instrumentality, through a narrowing of the world-thing into the sphere of exclusivity beyond the structure of utility and reward. The artist's relationship to the uncanny is one of fundamental affirmation: The artist can address the by now positively exhausted linden tree with the Goethean formula "So it is you". ${ }^{68}$ And the same holds true for the block of marble, the lump of clay, or the simple tool. There is, of course, no "dialogue" in the colloquial sense, because full mutuality still remains at a threshold, at a Vorschwelle. Yet there is an experience of being "addressed" by an otherwise mute member of the world in much the same way a work of art, or a book, or a beloved object can "speak" to us, for we can relate to it. "Art", Buber writes, "is the work and witness of the relation between the substantia humana and the substantia rerum, it is the realm of the 'between' which has become a form". ${ }^{69}$ The artist, then, is concerned not with "making" a thing but with "shaping" (Gestalten) a presence, and this figuration is no representation of sensual things, but a letting-happen of the between. Thus, Gestalt is a "mélange of You and $\mathrm{It}^{\prime}$. 70

Martin Heidegger, whose lectures on "The Question Concerning Technology" and "The Thing" were likewise delivered in Munich in 1953 and 1950, respectively, defined the substantia rerum, the Latin res, as "that which concerns us" (Angang) and which gradually assumes the meaning of ens, as "that which is present" (Anwesende). ${ }^{71}$ Accordingly, he refused the reduction of the everyday thing-such as a pottery jug - to its function and "use". The simple jug, for Heidegger, was at once the work (Gebild) of a potter, the walling of emptiness, the gift of pouring, the sanctification of an earthly spring, and a sacrifice for the gods-it was nothing less than a conjoining of heaven and earth: "The thing gathers together". ${ }^{72}$ Thus, the thing as thing must be approached "sparingly" and met with a certain "wakefulness". And the first step towards this wakefulness, writes Heidegger, "is the step away from the merely apperceptive, i.e., explanatory thinking into devotional thinking". ${ }^{73}$ But can such devotional thinking, which seems to belong to the artist's gaze more than to our common experience, help us approach the thing of technical machination?

Heidegger seemed to think so and included in his catalogue of thingness not only hand-made jugs but also the footbridge, the book, the crown, the cross, and the plow. It was art, or rather the poetic element underlying all art, which would pose the question of technology anew. Through art, technology could reflect on itself and come to its senses (Besinnung); because art and technology, while fundamentally different, are still close relatives. ${ }^{74}$ Thus art would remind technology that "what is decisive in techne does not lie at all in making or manipulating nor in the use of means, but rather in ... revealing". (Heidegger 1977, p. 13; German: Heidegger 1978, p. 17). Like art, technology is a way of revealing (Entbergung); it is a way of bringing forth (Her-vor-bringen); it is a poetic pursuit of truth. Modern technology, however, has forgotten its poetic challenge and replaced it with what Heidegger calls the Ge-stell, the "Enframing" that belongs to the human "mode of ordering" and "standing-reserve" (Bestand). ${ }^{75}$ This, for Heidegger, is technology's true "danger" and "destining" (Geschick): "Man stands so decisively in attendance on the challenging-forth of Enframing that he does not apprehend Enframing as a claim, that he fails to see himself as the one spoken to, and hence also fails in every way to hear in what respect he ek-sists ... "76 What technology, then, lacks, and what art can restore to it, is the ability to see oneself as the one spoken to, as Angesprochenen. What the modern age forgets is that technology takes part in the poetic process of revealing and that it "needs and uses man" so that he may "share" in it (Cf. Heidegger 1977, p. 32; German: Heidegger 1978, 
p. 37). Unlike the work and the thing that is not merely Zeug but gathers all dimensions of human culture, the Ge-stell is oblivious to our human participation.

\section{Work and Werk}

"Where there is no participation", Buber wrote in I and Thou, "there is no actuality". (Buber 1995, p. 113; German: Buber 2019a, p. 75). What Buber calls Verwirklichung has participatory character. It needs to pass through the world of It. Against Heidegger, whose work he forcefully rejected on both philosophical and moral-political grounds, Buber argued that dialogical realization had nothing in common with Fürsorge and Mitsein, that it was no compassion or sympathy, but a genuinely new form of affection, or attention (Zuwendung) that required, and acknowledged, a shared agency in letting the "between" manifest itself: "Beyond the subjective, and on this side of the objective, on this narrow ridge where I and You meet, lies the realm of the between". ${ }^{77}$ That this realm of the between was not limited to the interpersonal but could emerge also between an I and a thing commonly perceived as It, that it could transfigure the It to a You and the I to another self, we have already seen. That no factory and no office was entirely "devoid of creation" (schöpfungsverlassen) and that indeed a "worker can experience his relationship to a machine as dialogical", this remarkable claim Buber articulated in his "libellus cordis mei", in Zwiesprache, first published in $1932 .{ }^{78}$

It would certainly seem patronizing, even cynical, today for a philosopher of comfortable standing to assign dialogical meaning to a stomping machine on a greasy factory floor and to suggest that laborers earning less than minimum wage can enjoy intimacy with their tools. But there existed, in Buber's time, a long intellectual debate on Arbeitsfreude (joy in labor) tying together ideals of the Werkbund movement, labor Socialism, and religious ethics before, sadly, inspiring the vanguards of National Socialism. ${ }^{79}$ Buber himself relied on Hendrik de Man's 1927 case study of industrial workers "enjoying" their labor and frequently invoked the romantic concept of Werkgemeinschaft (community of work) so popular in upper-class German salons at the time. 80 "A community of faith", Buber wrote in 1931, "can be true to itself only of it is a Werkgemeinschaft". ${ }^{81}$ When queried later by the American theologian Paul Pfuetze as to how his I-Thou theory would fare in "great industrial aggregates", such as Detroit, New York, or Essen, Buber invoked the model of the Kibbutz as a possible experiment to test out his theory of comradeship and neighborliness in industrial communities (Cf. Rome and Rome 1964, pp. 39, 75). But on a more philosophical level, he also spoke of how the two aspects of "It" and "You" would not only coexist but, in fact, "co-operate in the human construction and reconstruction of a 'world' accessible to human thought". (Rome and Rome 1964, p. 57). The bifurcation of It and You, then, which was rooted in the polarity of the basic words I-You and I-It, had to be understood as one of mutual aid and inter-participation, as an ontological Werkgemeinschaft in its own right. In practice, Buber pointed to Kropotkin's model of concrete labor solidarity as a counter-model to the division of labor distorting the authentic ideal of Werkgemeinschaft: "He [Kropotkin] sketches the picture of a village based on field and factory alike, where the same people work in the one as in the other alternately without this in any way entailing a technological regress, rather in close association with technical developments and yet in such a way that man enters into his rights as a human being". (Buber 1958b, p. 45).

Here, then, Buber found inspiration for a Werkgemeinschaft that could at once engender the romantic ideal of medieval guilds, the Zionist ideal of working the land, and the modern ideal of technological production. The unfortunate objectification of labor lay not in the type of work or in its tools (such as nature standing in for "You" and factories for "It") but in its division: In the division of labor among workers and between social classes, as well as in the division of labor between workers and their tools. And we can now begin to make sense also of Buber's "dialogue" with machines: A machine becomes "human" not by assuming human qualities or by doing human work, but by inviting our participation and by participating in the creation of a distinct "between". The most obvious examples of such machines would be musical instruments, which remain lifeless things without their 
master and yet participate in producing a "between" no virtuoso could produce alone. No musician would think of a violin as merely a tool, or a piano as merely a mechanical or electronic device, unless it was a self-playing Pianola. Nor would a violin or piano come to life were they regarded merely as decorative works of craftsmanship. Their thing-self, as it were, lies not in their function, nor in their form, nor even in their purpose but, literally, in their intimate participation-in shared labor. Instruments neither work for us nor on our behalf; they work with us. ${ }^{82}$ And with us work also the countless hands of their co-creators, a long chain of unacknowledged collaborators, who are present in every sound as an invisible Werkgemeinschaft. Thus, each sound emerging from an instrument is itself a symbol of culture as participatory cooperation. It is a symbol of humanity. And an artist working with an instrument will draw this "lifeless thing", as Buber puts it, "into the longing for dialogue", thus "giving it a soul and rights". 83

\section{Towards an Ethics of Things}

Giving rights and a soul to lifeless things may not be intuitive to readers attuned to the language of Verdinglichung, or objectification, and rightly anxious about our indisputable addiction to shiny things and gadgets. It also may raise concerns about a radical ethics of "equal consideration" that no longer acknowledges human-specific dignity and the priority of personhood. ${ }^{84}$ But dialogue, to Buber, meant precisely the unusual possibility of Entdinglichung, or de-objectification, that would elevate not only the dignity of things but also the dignity of their "users". An object, as we have seen, can indeed become present. It can begin to "mean" something to us, and this meaning, or lack thereof, establishes the ground for what Silvia Benso, drawing on Heidegger and Levinas, has poetically explored as the ethics of things, which, as all ethics, must be an ethics of relation. "Things possess a reality in themselves that cannot be postponed or dislocated", writes Benso, " . . a thing is richer than the sound, the taste, the smell of it the I may-does indeed-enjoy. It contains memories of an unreachable past, of the ancestral dance of the earth and the elements, of the eternal play of light and darkness, of being, but always as beyond-being". ${ }^{85}$ Here emerges an "imperative" of things and a "touching mode of tenderness", the possibility to face a thing without desire for possession. Here, Benso argues, a thing is left to "presencing". It ceases to be Gegenstand to be touched, and cared for, into Gegenwart. "The reality of things", Alphonso Lingis writes in a similar vein, "is not given in our perception, but orders it as an imperative". (Lingis 1998, p. 63). We do not stand before things but are "continually implicated" in them.

Heidegger's early reflections on things as pragmata of our "concernful dealings" (besorgender Umgang) opened the space for relational thinghood and for the rehabilitation of what he described, in Sein und Zeit, as Zeug (equipment) (Heidegger 2001, p. 68; English: Heidegger 1962a, p. 96). To be sure, equipment first appears as a purposeful thing, as a thing of service, as a Werkzeug, and therefore as an It in Buber's sense. But it also points to the meaning of Werk itself, to the making and materiality always referencing a world of nature and world of human historicity. The work, Heidegger writes, is cut to the figure of the person who is to use, to handle, or to wear it. Indeed, the human being is there along with the work as it emerges. "Thus", continues Heidegger, "along with the work, we encounter not only entities ready-to-hand, but also entities with Dasein's kind of Being ... and together with these we encounter the world in which wearers and users live, which is at the same time ours". (Heidegger 1962a, p. 100; German: Heidegger 2001, pp. 70-71). In every thing, then, is disclosed the very solidarity of labor and community of fate that we have seen in Cassirer and Dessauer, and which formed Goldstein's understanding of technology as a form of social communion. But this disclosure must be brought forth, it must be revealed in praxis, in our relation to things. It must be actualized, verwirklicht. A thing is never just a thing but, as the Hebrew term davar suggests, a word, an act of speech, an event, a story. And like any word it needs a listener and one to respond.

And here may also lie the deeper meaning of Buber's pragmatic answer to the distraught members of the Kibbutz: A Kibbutz must not function like a mechanical city but as 
a cooperative Werkgemeinschaft encompassing the human, the natural, the thing-world, and the "spiritual" alike. This fourfold solidarity, or attentiveness, which echoes Heidegger's fourfold situatedness of things, defined Buber's little explored understanding of "work", which was central to his Zionism and his critique of Herzl's technocracy. Herzl wanted to turn machines into the new "slave-workers" of humanity; Buber wanted to "humanize" them into partners in a working community. For Buber, as for Cassirer, technology had to become integral to human culture as gemeinsames Tun. "It is possible", Buber tells the Kibbutz members, "to impart on the worker a relationship to the work or to the workshop as a whole, to what he does and to what his colleague does". ${ }^{86}$ Max Brod's distinction between mechanical labor and "work at one's own work" could have reflected Buber's own position: For the "worker working on his own work", Brod writes, "work and soul have become one. The work expands into indefinite meaning and, as it participates in the infinite, enters the sphere of the religious". 87 "Mere labor does nothing of the like", Eugen Rosenstock-Huessy once wrote. "Participant labor (Mitarbeit) does magic; we purchase a piece of ubiquity and a small stretch of eternity". ${ }^{88}$ For Buber, as for A. D. Gordon, all work should strive to be realization-Verwirklichung, or Avodah, whose twin connotations of service and prayer suggested a striving also for sacralization. And if an instrument, a tool, or a machine was needed for this striving, then it should be seen, like the Baal Shem's household things, not as mere Zeug, but as participant in redemption. This, one could argue, was Buber's version of techno-optimism. ${ }^{89}$

To treat a thing with respect, to care for things and let them be, to give them rights, such as the right to be maintained, to be repaired, or to be saved from preordained obsolescence is no trivial expansion of "dialogue". It may be an ecological necessity. Of Rabbi Menahem Mendel of Kotzk it is said that he kept his old worn clothes, commenting: "A coat that once honored man should not be treated with contempt once it is no longer being used ... If it beautified you when it was new, why would you reward it with evil?" 90 We cannot care about nature without caring about things. And we cannot care about things without caring about the people producing them, and without seeing products as works designed by human minds and made—-no matter how much machine may be involved-by, and for, human hands. To preserve this "manuality" of things and stem the wave of unnecessary, often frivolous, automatization where man would be but an "external limb of the machine", belonged to Buber's program of humanizing technology. ${ }^{91}$ Erich Fromm would later speak of a "trans-utilitarian" approach to technology which he derived from his interpretation of Marx: "In practice I can only relate myself in a human way to a thing when the thing is related in a human way to man". ${ }^{92}$ In the afterword to I and Thou, written in 1958, Buber reiterated that the ability of saying-you (Dusagen) exists towards both the lifeless and quick, because this ability is, in truth, a conscious disposition, a way of conduct (Haltung), a readiness to meet humanity in everything around us (Buber 2019a, p. 246). To allow this attitude to flourish and to ensure that the leisure of saying-you, the privilege and imperative of dialogue (and dialogue is a privilege as much as an imperative), was a right afforded to every "I" - this, for Buber, was the task of creating a humanized environment of work or, as Erich Fromm put it, a "humanist industrial society". 93

The humanization of technology Buber demanded from the members of the Kibbutz was rooted in this task and in his belief that things can participate, and must allow us to participate, in the unfinished project of creation. This project, as Dessauer had intimated long before and as Hans Jonas would later write, called for a "cosmic responsibility" and a new "interhuman solidarity". (Jonas 1987, p. 47). "Solidarity of all factions in the burning struggle for humanity", Buber noted in 1953, is our "highest earthly duty". 94 The greatest challenge for humanity at this historical hour came from technology itself. It was "man's voluntary enslavement into the service of nuclear fission". ${ }^{95}$ Its greatest adventure was the age of space travel. Neither of them seems to be of particular concern to us today (although they probably should). But both were global challenges at their time that required a global response and could not be satisfied by factory reforms or You-moments with machines. 
At this junction of technology's unprecedented reach and destructive potential, humanity, Buber believed, would have to finally "show itself". It would have to decide what kind of homo faber it wanted to be and whether the things we make would illuminate our world or burn it. And when this happened, we would get to know anew not only a de-familiarized world around us but also, and more importantly, ourselves. ${ }^{96}$ And then, perhaps, we would come to know what Buber's younger contemporary, the philosopher Günther Anders, suspected long ago: That "man is smaller than himself" (Anders 1968, p. 264).

Funding: This research received no external funding.

Conflicts of Interest: The author declares no conflict of interest.

\section{Notes}

1 Buber's exchange with the Kibbutz members was recorded by Abraham Shapira and originally published in his Kibbutz journal Shdemot. A German transcript, which is quoted here, appeared in (Buber 1985, pp. 300-12; for the quote see p. 310). All translations, unless noted otherwise, are by the author.

2 Indeed, A. D. Gordon, who significantly influenced Buber's own understanding of Zionism, envisioned a spiritual and national rebirth of the Jewish people through labor; but what he had in mind was dignified, self-motivated manual labor-“labor not by force, but the work through which the human being can feel organically and naturally connected, and which allows the people to be in harmony with its culture rooted in labor and soil". (Gordon 1929, p. 65). On Buber and Gordon see (Schweid 1983, pp. 270-88) and, more recently, (Lahav 2014). Gordon's essays are now available in a new Hebrew edition (Gordon 2020). See also the treatment of Gordon along with other anarchist and "green" aspects of the Kibbutz movement in (Horrox 2009).

3 (Buber 1985, p. 312). A different version of the story appears in (Buber 1967, p. 184): "I climb upward, in fact, just in order to erect this sign up above. I hold it, and it holds me". And Buber continues that the human spirit "may not cast off the burden of its civilization; for in it a higher value is hidden that will only shine forth when from the sphere of inner conflict it attains the pure summit air of justice and peace".

4 Cf. (Rome and Rome 1964, p. 58). Here, Buber also speaks of the "narrow rocky ridge". In Daniel, Buber already argued for the overcoming of the "duality of all things" that would require a descent into the abyss of uncertainty ("ewig neu angelobt der heiligen Unsicherheit"). Cf. Martin Buber, “Daniel: Gespräche von der Verwirklichung”, in (Buber 2001, p. 216).

5 Martin Buber, "Replies to my Critics", in (Schilpp and Friedman 1967, p. 722). Buber's response first appeared as a "philosophische Rechenschaft" in the Neue Rundschau in 1961. See: (Buber 2017, p. 501). Buber also introduced here the line of demarcation.

6 For a discussion of Buber's “ecological thinking" see (Breslauer 2019, esp. pp. 156-70); also (Tirosh-Samuelson 2017a, pp. 179-93). To date, one of the most thoughtful studies addressing Buber's views on technology and the It-World remains (Balogh 1969). An instructive chapter on Buber and technology appears in (Oldemeyer 2007, pp. 67-82). See also the helpful essay by (Muth 2020, pp. 99-106) and the excellent discussion by (Nelson 2014).

For the "transhumanist" turn see (More and Vita-More 2013) as well as (Tirosh-Samuelson 2012) and (Tirosh-Samuelson 2017b). Martin Buber, "Ich und Du", in (Buber 2019a, p. 66). See also Buber's 1945 radio lecture "Über die große Krise”, reprinted in (Buber 2019c, p. 81).

9 This essay does not attempt a definition of technology, though it accepts, for historical purposes alone, Werner Sombart's basic definition of Technik and, by extension, technology as "alle Verfahrensweisen, alle Mittel, alle Komplexe, alle Systeme von Mitteln zur Erreichung eines bestimmten Zweckes" and his distinction between Instrumentaltechnik and Produktionstechnik. Cf. (Sombart 1911, pp. 63-64). That said, Sombart's thinly veiled antisemitic interpretation of technology must not be ignored. See (Herf 1986, esp. pp. 133-38). For a wide-ranging summary of definitions of technology up 1956, which covers the historical period of this essay, see (Dessauer 1956, pp. 230-35). For more recent definitions see (Mitcham 1994) who relies heavily on Dessauer. See also the chapter on Dessauer therein, pp. 29-33.

10 (Herf 1986, esp. pp. 18-48). Herf speaks of "reactionary modernism" in paradoxical terms describing it as a peculiar juxtaposition of "great enthusiasm for modern technology" and the simultaneous "rejection of the Enlightenment and the values and institutions of liberal democracy". Herf, in fact, documents not only the conservative glorification of technology (which also characterized the affinities between Futurism and Fascism), but the conservative ambivalence towards technology and its pessimism. See also (Herf 1981, esp. pp. 806-7).

11 Buber indeed insisted not to speak of a "general supremacy of the life of dialogue". Cf. (Rome and Rome 1964, p. 40).

12 (Buber 1995, p. 55). German: (Buber 2019a, p. 40). Buber plays here with erfahren (experience) and befahren (touching the surface) to stress the distance and superficiality of the I-It.

13 Cf. (Buber 1960, pp. 170-71). Also idem, “Sinnbildliche und sakramentale Existenz im Judentum” (1935), now in (Buber 2017, p. 171). See also (Bloch 1968, esp. p. 30), where Bloch discusses Buber's concept of "sakrale Handlung" and "Sakramentgeschehen". 
(Buber 1958a, p. 105). Originally as "Das Leben der Chassidim", introduction to Die Legende des Baalschem (1908), now in (Buber 2018a, p. 190). For the quote from the Baal Shem see Martin Buber, Des Baal-Schem-Tow Unterweisung mit Gott, now in (Buber 2016, p. 107).

(Flusser 1993, p. 11): “[D]as Vulgäre zu entvulgarisieren (und zu sakralisieren?)”.

Cf. "Mein Liberalismus”, in (Buber 2018b, pp. 382-83).

"Wenn Herzl noch lebte", in (Buber 2019c, p. 38).

(Buber 2019c, p. 39). For the larger context see also (Penslar 1991).

(Herzl 1934, p. 24). Herzl considered machines "Arbeitssklaven von unerhörter Kraft".

(Habermas 2003, pp. 44-53). Also Martin Heidegger, “Vom Wesen und Begriff der Physis: Aristoteles, Physik, B.1” (1939), in (Heidegger 2013, pp. 239-302, esp. 289), where Heidegger considers "Machen" and "Wachsen" as two distinct forms of production.

The dedifferentiation of the grown and the made, however, was already imagined as an inherent continuity between the organic and mechanical by Ernst Kapp who, in his famous projection theory, defined all technical innovation as an "Organprojection" and extension of the human body (Kapp 1877, pp. 29-39).

(Buber 1995, p. 83). German: (Buber 2019a, p. 57). Where Kaufman writes "lacks density" Buber actually uses the German word "undicht", which suggests a sort of porousness later developed by Ernst Bloch as "das Übergleitende von Nähe und Ferne". Cf. Ernst Bloch: "Italien und die Porosität" (1925) in (Bloch 1965, p. 158).

(Buber 2019c, p. 41). Buber's critique of Herzl's "liberalism" echoes, in fact, Landauer's critique of Marxism in his Aufruf zum Sozialismus (1911), where the Marxist belief in progress and "Wissenschaftsaberglaube" is depicted as naïve scientism and prophetic reliance on technology: "Der Vater des Marxismus ist der Dampf. Alte Weiber prophezeien aus dem Kaffeesatz. Karl Marx prophezeit aus dem Dampf". (Landauer 2017, p. 52). On the interwar critique of culture see especially (Lieber 1974).

See (Mendes-Flohr 1978), esp. chapters 1 \& 2. See also the classic work by (Kohn 1979, pp. 186-210). More recently, (Löwy 2018, pp. 131-39).

Martin Buber, "Alte und neue Gemeinschaft", in (Buber 2013, pp. 64-65). On an analysis of the text see (Mendes-Flohr and Susser 1976).

Cf. Martin Buber, “Worte an die Zeit: Gemeinschaft" (1919), in (Buber 2019b, p. 162). Likewise, Tönnies spoke of society as "mere coexistence of people independent of each other". (Tönnies 1963, p. 34). Also ibid., p. 35: "Accordingly, Gemeinschaft should be understood as a living organism, Gesellschaft as a mechanical aggregate and artifact". On Buber and Tönnies, see (Susser 1979, esp. 105-8). Also (Susser 1981, pp. 14-16).

(Buber 2019b, p. 166). In I and Thou, Buber distinguished between Gemeinschaft and the "Verlies der Sozialität". (Buber 2019a, p. 101). Buber's embrace of Gemeinschaft may also have been a response to Werner Sombart's identification of "Jewish" capitalism with Gesellschaft as opposed to Christian medieval Gemeinschaft. Cf. (Herf 1986, p. 136). See also (Mendes-Flohr 1976, esp. p. 92) for a discussion of Sombart's identification of capitalism with "factory discipline" and a "great mechanism" that is set in motion by the "spirit of Moloch" and, ultimately, by the "Jewish species" of the bourgeois "trader".

(Buber 2019b, p. 164). Friedrich Georg Jünger, by contrast, would later advocate the return from a rational Geistgemeinschaft to a self-authenticating Blutgemeinschaft. Cf. (Jünger 1928, p. 21).

(Tönnies 1963, p. 249). The relation between the mechanical and machination (Machenschaft) would become a significant aspect in Heidegger's critique of technology. See (Joronen 2015), (Steinbock 2015), and for Heidegger's antisemitism (Hadad 2018, pp. 201-20). More recently and with special attention to Heidegger's notorious Black Notebooks, (Lapidot 2020, esp. pp. 104-6).

Cf. (Rousseau 1973, p. 177). See the excellent studies by (Meyer 1969) and (Stollberg-Rilinger 1986, esp. pp. 202-28). It is important to note that early images of the mechanical state, just as the notion of the "mechanical man", were not necessarily negative, but often reflected a genuine belief in rational and organizational social structure. This applied especially to Hobbes, who experienced a certain renaissance in Carl Schmitt and, later, Leo Strauss.

See (Herder 1784, pp. 401, 291). Also (Rousseau 1973, p. 271), where Herder speaks of the "Maschinenwerk der Revoution". Saul Ascher used similar language in 1801 when he argued that revolutions would turn the individual into a "selbständige Maschine" whereas conservative statecraft would render the individual a "part acting on behalf of a great machine". (Ascher 1801, pp. 193, 136).

(Fichte 1923, pp. 100, 129, 101). On the Jewish reception of Fichte see (Voigt 2003).

Cf. (Gans 2005, pp. 212-15). On Gans's “revolutionary” reading of Hegel see (Riedel 1967, esp. pp. 257-63).

(Thoreau 2014, p. 322). Also, Martin Buber, “Über den Bürgerlichen Ungehorsam: Zum 100. Todestag von Henry Thoreau” and “Nochmals über den Bürgerlichen Ungehorsam", in (Buber 1966, pp. 213-17).

(Kapp 1877, p. 344). Kapp, however, argued for the ultimate cooperation between machine and organic elements in the state. (Goethe 1977, Book 3, chp. 13, p. 460). This poignant passage appears in several studies on technology published in the early 1900s. 
(Baker 1857, Canto IX, p. 179). Baker indeed believed that the "great achievements of the Flame-Powers" would, "in a truly Christian spirit", as he wrote in the preface, "aggrandize and elevate the human race". Preface, ibid., iii. For a discussion of Baker's poem and its Victorian context see (Viereck 1949, pp. 90-91).

(Arnold 1994, p. 34): "Faith in machinery is, as I said, our besetting danger; often in machinery most absurdly disproportioned to the end which this machinery, it is to do any good at all, is to serve; but always in machinery, as if it had a value in and of itself. What is freedom but machinery? what is population but machinery? what is coal but machinery? what are railroads but machinery? what is wealth but machinery? what are religious organisations but machinery?"

For an excellent survey of Jewish imaginations of decadence and decay see (Vogt 2015, pp. 75-102). For the Jewish reception of Nietzsche see especially (Stegmaier and Krochmalnik 1997). On Buber and Nietzsche specifically see (Mendes-Flohr 2001).

Cf. (Braun 1992, pp. 172-206). The sense of technological war (and gruesome victory of technology) was perhaps most dramatically, and prophetically expressed in Georg Kaiser's stage trilogy Die Koralle (1917), Gas 1 (1918), and Gas 2 (1920). See the discussion in (Stern 1965) and the brief reflection on Kaiser's influence on Thea von Harbour and Fritz Lang's Metropolis in (Gittleman 1979).

Cf. (Lessing 1930, p. 112) and (Lessing 1981, pp. 16, 28, 43). Lessing, writing two years before Buber's seminal work, imagined a community "beyond I and You". "Where community is alive, there is no I and You ... Nature knows neither an I nor a state". (Lessing 1981, pp. 27, 60). On Lessing see also (Albert 1994, pp. 30-45).

(Klages 1920, pp. 30, 33, 127). On Klages and technology see also (Oldemeyer 2007, pp. 57-66), (Furness 2000, pp. 99-123), and (Lebovic 2013). Yotam Hotam has recently analyzed the troubled role of Klages in the Kulturkrise and pointed to the interactions with Buber. See (Hotam 2013, esp. pp. 55-72).

(Spengler 1931, p. 74). On Spengler's pessimistic and deeply racist views of technology see (Dessauer 1956, pp. 36-42). Herf, however, shows that Spengler's view on technology was ambivalent, rather than completely pessimistic. More generally see (Grigenti 2016).

Cf. (Mumford 1970). Based on the 1962 Saposnekow Lectures at City College in New York and an earlier study, Technics and Civilization (1934), Mumford's Myth of the Machine offered, with all its faults and fears of Hippie "barbarism", a rather perceptive analysis of technocracy, computerization, and biotechnology. For Karl Jaspers, see especially (Jaspers 1949, pp. 127-60) and (Jaspers 1979, pp. 32-60). The latter text was written in 1930 and republished in 1946. In (Jaspers 1958), the discussion of technology shifts towards political or, as Jaspers puts it, meta-political (überpolitische), responsibility. This coincides, incidentally, with Buber's own use of "meta-politics". A later generation of Technikphilosophen included, of course, Erich Fromm and Hans Jonas.

(Coudenhove-Kalergi 1922, p. 50). On Coudenhove-Kalergi's childhood and life see (Coudenhove-Kalergi 1958, pp. 15-56). The Kulturkritik of Buddhism, which appeared already in Leo Baeck and other Jewish religious leaders at the time, still continued in Theodor Adorno, who attacks the "kitschigen Exotismus kunstgewerblicher Weltanschauungen", such as the "erstaunlich konsumfähigen Zen-Buddhismus". (Adorno 1966, p. 74). On Baeck's critique of Buddhism see (Meyer 1999, p. 109). Also (Weiss 2017).

(Coudenhove-Kalergi 1922, pp. 47-48). This, however, did not render him a "feminist" in the positive sense. Like Werner Sombart, who made a similar argument, Coudenhove-Kalergi, remained contemptuously critical of the emancipation of women: "Die Frauenemanzipation bedeutet den Triumph des Mannweibes über die wirkliche, weibliche Frau; sie führt nicht zum Siege, sondern zur Abschaffung des Weibes". Cf. also (Sombart 1911, p. 73): "Die moderne Frau ist ja entstanden dadruch, daß die alte Hauswirtschaft zusammengebrochen ist und sie Zeit bekommen hat".

See (Rathenau 1919, esp. pp. 45-157). Also, (Rathenau 1918, pp. 30-31): “Denn das Wesen der Mechanisierung schließt Universalität ein; sie ist die Zusammenfassung der Welt zu einer unbewußten Zwangsassoziation, zu einer lückenlosen Gemeinschaft der Produktion und Wirtschaft ... Auf unserm Gestirn hat die Mechanisierung einen großen Teil ihrer Aufgabe erfüllt". (Plessner 1985, pp. 31, 39). On Plessner see also (Müller 2002, pp. 139-61).

Cf. (Dessauer 1928, p. 58): “In den Gegenständen des vierten Reiches ist Wesentliches, das durch menschliche Aktion hindurchgeschritten ist". Also (Dessauer 1956, pp. 158-66).

(Cassirer 2011, p. 79). “Cooperative" seems to best render Cassirer's intention of "gemeinsam" in this context. The English translation omits this passage. Cf. (Cassirer 1961, p. 143). Ernst Cassirer, "Form und Technik" (1930), in (Cassirer 1985, p. 40). (Cassirer 1985, p. 48). The fundamental ontological and ethical distinction between erkennen and anerkennen appeared already in Cassirer's teacher Hermann Cohen. Cf. (Cohen 1929, pp. 15, 56). (Cassirer 1985, p. 89). Cassirer insists on what he calls the "Sachdienstgedanke" and refers here, interestingly, to both, CoudenhoveKalergi and Dessauer borrowing, from the latter, the notion of "Freiheit durch Dienstbarkeit".

On Goldstein see, most recently (Zuber 2008, esp. pp. ix-xxxi) and (Dipper 2017). The Julius and Margarete Goldstein papers are archived and digitized at the Center for Jewish History (AR 7167/MF 720).

56 This has been shown by David Groiser in (Buber 2012, esp. pp. 35-38). See also Asher Biemann in (Buber 2003, pp. 9-68). At the same time, however, the fin-de-siècle return to mysticism signaled a new interest in free "religiosity" rather than institutional 
religion and the persuasion "dass lebendige Religion weder von bloßen Reflexionen noch von bloßen Imperativen, geschweige von einem verhärteten Dogmatismus oder Moralismus leben kann, sondern in jedem Menschen neu geboren werden muss". (Hoffmann 1913, p. 611). For context see also (Spörl 1997.)

Martin Buber, "Ekstatische Konfessionen”, in (Buber 2012, p. 56).

(Buber 2001, p. 187). Analyzing Buber's arboreal dialogues, H. Paul Santmire has proposed to introduce a third category of relationship-the "I-Ens". See (Santmire 1968, esp. pp. 266-69).

The difficulty of translating Buber's term (Grund-)haltung is evident. Kaufmann translates Haltung as "attitude", which does not fully capture the meaning of how, and with what state of mind, we conduct or comport ourselves towards another. It can be argued that Buber's Haltung corresponds to Heidegger's Verhalten, which is often translated as "comportment".

(Buber 2019a, p. 75). English: (Buber 1995, p. 112). As to be expected, the "You" is identified not with dying but with a "breath of eternal life". Also, (Buber 2019a, p. 65): "Das Grundwort Ich-Es ist nicht vom Übel—wie die Materie nicht vom Übel ist".

For an excellent discussion of Buber's distinction between Schicksal and Verhängnis see (Balogh 1969, pp. 74-76).

Martin Buber, “Urdistanz und Beziehung”, in (Buber 2019a, p. 203). The text was written in 1948 and first published 1950.

(Buber 1995, p. 90). German: (Buber 2019a, p. 60). The translation has been altered.

Martin Buber, "Religion als Gegenwart”, in (Buber 2017, p. 88). English: (Horwitz 1988, p. 20).

(Horwitz 1988, p. 85). German: (Buber 2017, p. 133). In I and Thou, this will be called the "Eternal Thou". Incidentally, Ludwig Klages, in "The Concept of Personality" of 1916, defined the "immutable eternity" of God as addressable only as a You: "Daher müssen wir dieses Wesen entweder mit dem Ausdrucke: Du bist, oder mit dem bei einigen Alten gewöhnlichen: Du bist eins ehrfurchtsvoll begrüßen". (Klages 1920, p. 83).

Cf. (Buber 2017, p. 124). English: (Horwitz 1988, p. 69): “ . . the extent to which this inherent Thou, the inherent relationship, entails a task for the human being..."

Max Picard, who was deeply influenced by Buber, and whose phenomenology of the human face was an important source for Levinas's ethics, alluded to this surplus of meaning as lacking in technology: "Die Maschine kennt kein Mehr" and "Das Ding ohne Mehr ist nur es selber". Picard, “Wo steht heute der Mensch?” in (Picard 1960, pp. 99, 105). Note also (Picard 1929, esp. pp. 13-22), where Picard describes the divine surplus of the human countenance and develops a phenomenology of seeing that resembles the ontology Buber's dialogical encounter.

Likewise, in I and Thou, we hear Goethe speak to the Rose: “Du bist es also". (Buber 2019a, p. 77).

Martin Buber, “Man and His Image-Work", in (Buber 1965, p. 165). German as “Der Mensch und sein Gebild”, in (Buber 2017, p. 463).

Cf. (Buber 2017, p. 462). English: (Buber 1965, p. 164). In I and Thou, Buber speaks of Gestalt as "Mischung auch von Du und Es". (Buber 2019a, p. 108).

Cf. Martin Heidegger, "Das Ding”, in (Heidegger 1978, pp. 167-68). The essay is based on a lecture Heidegger delivered on June 6, 1950 at the Bayerische Akademie der schönen Künste in Munich during the inaugural conference of what would become a regular convention under different themes. Buber, in fact, participated in the 1954 conference with his lecture on "Der Mensch und sein Gebild" and, beginning in 1957, became involved in organizing a conference on language ("Wort und Wirklichkeit"), where he presented, in 1960, the lecture "Das Wort das gesprochen wird" ("The Word that is Spoken"). It was in this context that Buber, in May 1957, engaged in extended conversations with Heidegger. See especially (Mendes-Flohr 2014). For an excellent account of Buber's post-war reception in Germany, including his visits to Munich, see (Gillman 2014); also the instructive chapter on Martin Buber in (Boos 2014, pp. 25-51).

(Heidegger 1978, p. 166). In his earlier lectures, “Die Frage nach dem Ding” (1935/36), Heidegger framed this point in terms of Geschichtlichkeit. Cf. (Heidegger 1962b, pp. 37-41). Also (Benso 2000, pp. 59-66).

(Heidegger 1978, p. 174). Heidegger speaks of "das andenkende Denken". This position corresponds to a certain Gelassenheit (releasement) when it comes to things: "We can use technical devices, and yet with proper use also keep ourselves so free of them, that we may let go of them any time. We can use technical devices as they ought to be used, and also let them alone as something which does not affect our inner and real core. We can affirm the unavoidable use of technical devices, and also deny them the right to dominate us, and so to warp, confuse, and lay waste our nature". (Heidegger 1966, p. 54). Mark A. Wrathall has recently put Gelassenheit and Besinnung in the context of Heidegger's "sober thinking". See (Wrathall 2018, pp. 13-38, esp. pp. 30-32). Also (Crowell 2018, pp. 74-95, esp. pp. 86-87). On Gelassenheit in Heidegger's juxtaposition of Hölderlin and Angelus Silesius see (Babich 1995, esp. p. 272). On Hölderlin and Heidegger with respect to technology see (Klein 2020, pp. 309-37). Daniel Morat has brilliantly chronicled the unsavory intellectual genealogy of Gelassenheit in Heidegger and the Jünger brothers (Morat 2007).

Cf. Heidegger, “Die Frage nach der Technik”, in (Heidegger 1978, p. 39). English: (Heidegger 1977, p. 35).

Cf. (Heidegger 1977, pp. 19-24). Heidegger's Ge-stell has been rendered also as “im-position”. See (Dahlstrom 2018, pp. 39-56, esp. p. 55n10).

(Heidegger 1977, p. 27). German: (Heidegger 1978, p. 31). On “ek-sists” and Heidegger's use of ekstasis see (Sallis 1983, esp. pp. 93-94). 
Buber, "Das Problem des Menschen", in (Buber 2017, p. 311). On Buber's philosophical critique of Heidegger, (Buber 2017, pp. 271-88). For the concept of Zuwendung, ibid., p. 305. For his political critique on Heidegger see (Buber 1957, esp. pp. 75-77). See also (Novak 1985, esp. pp. 129-34).

Martin Buber, "Zwiesprache", in (Buber 2019a, pp. 145-46). The cited portion of the text had, in fact, been published already in 1929 in the journal Die Kreatur. Buber called Zwiesprache the "little booklet of his heart" and, accordingly, dedicated it to his wife Paula.

79 See (Campbell 1989). As Campbell shows, the German concept of labor and work was elastic enough to find echoes in both Marxist and National Socialist circles. In his critique of Marxism, Landauer, too, invoked a socialism of "freudige Arbeit" (Landauer 2017, p. 47). On the darker side, it was Ernst Jünger's Der Arbeiter (1932), whose ideal of "totale Mobilmachung" resonated with National Socialist philosophies of labor. Cf. (Jünger 1981, esp. p. 103). Also (Jünger 1931). For a discussion of Jünger's work see (Grigenti 2016, pp. 29-40). Note also (Rabinbach 1992) and, most recently, (Haffter 2021).

Buber's insights about worker's relationships to machines were drawn from case study 69, where a printer recounts his “conversations" with a machine (de Man 1927, esp. p. 103). De Man's study covered 78 cases with different degrees of Arbeitsfreude (some lacking joy altogether) and offered strategies of identifying the obstacles to joyful labor. On de Man, see most recently (Milani 2020).

Buber, "Bemerkungen zur Gemeinschaftsidee" (1931) in (Buber 1966, p. 76): “Glaubensgemeinschaft ist es wahrhaft nur dann, wenn sie Werkgemeinschaft ist". For the notion of Werkgemeinschaft or Werkgemeinde see Buber, "Rede über das Erzieherische" (1926), in (Buber 2005, pp. 139-40): “Sowie der wirkende Mensch in eine Sache eintritt, wo er Werkgemeinschaft mit anderen entdeckt und übt, folgt er nicht mehr dem Urhebertrieb allein”. See also (Mendes-Flohr 2006, pp. 219-30).

Karl Bücher, in fact, built his understanding of dignified, humanized labor on the model of rhythmicity. Where machines become less rhythmical, or "musical", work ceases to be a cooperation between worker and machine: "Damit schwindet die alte Musik der Arbeit, welche die rhythmisch gehenden Maschinen noch deutlich erkennen liessen, aus den Werkstätten ... der Mensch ist ein Knecht des nie rastenden, nie ermüdenden Arbeitsmittels geworden, fast ein Theil des Mechanismus, den er an irgendeiner Stelle zu ergänzen hat". (Bücher 1896, p. 115). Cf. (Buber 2019a, p. 146): “ . . ein lebloses Ding, ihm Seele und Rechte verleihend ... " The question of "rights" for things has been on ethicist's minds for a while. See, for instance (Singer and Sagan 2016, pp. 291-94).

On this point see (Krantz 2002, esp. pp. 97-117). Obviously, we should hope, that the life of a thing, or a tree, or a horse, would not, in an extreme case, take priority over the life a human being, unless we believe that our human right to live depends on merit and moral worthiness. It is important to note here that Buber, despite his conviction that there existed no "radical evil", did not believe in the dialogical redeemability of all human life, but made it very clear that a human being, such as a Nazi perpetrator, could forfeit his or her place in humanity. If Buber considered the execution of Eichmann in 1962 a "mistake of historical dimension", he did so not on humanitarian grounds but because he worried that it might "serve to expatiate the guilt felt by many young persons in Germany". See (Arendt 1994, p. 251).

(Benso 2000, p. 137). A different approach to thing-ethics appears in (Flusser 1993, p. 82). Flusser criticizes, in fact, the "bürgerliche Dingmoral" of "Erzeugung, Speicherung und Verbrauch von Dingen" for its loss of "value" attached to things, value not in the economic sense, but of what we value in a thing. An early phenomenology of things that anticipated today's attention to material culture appears in Oskar Bie's discussion of furniture as a form of Gegenwart and persönliches Verhältnis. Cf. (Bie 1908, pp. 10-15). (Buber 1985, p. 311). Werk, in German, can mean the product of work (or work of art), but also workshop or factory. In fact Buber cites a recent visit to the Olivetti factories in Italy where the working conditions had been improved without any loss of productivity. Similar observations of working Partnerschaft appeared in (Michel 1960, esp. pp. 267-74). Michel, who dedicated the original edition of his book (1947) to Eugen Rosenstock-Huessy and was deeply influenced by Buber, called for an "echtes Miteinander in der Wirtschafts- und Betriebsgestaltung" on the basis of "echter Begegnung" (p. 269).

(Brod 1920, p. 43). See also (Arendt 1998, esp. pp. 79-84), where Arendt discusses the distinction between labor (ponos) and work (ergon). Interestingly, Arendt draws also on Karl Bücher (p. 145) and Hendrik de Man (p. 140).

(Rosenstock-Huessy 1955, p. 175). Like Buber, and drawing on Ernst Michel, Rosenstock-Huessy argued for a new sense of partnership and "fraternity" in factory and office. "Der Partner ist also hier eine Mehrzahl von Menschenkindern. Erst dank ihrer Eingliederung in einen Arbeitsgang werden sie fähig, zum Partner des Unternehmens sich zu verbrüdern" (p. 140). Thus, the concept of Mitarbeit involved a sense of co-creatorship. A co-worker, like a citizen, is one who could rebuild the factory, or the city, after its destruction (pp. 190-99).

For the moral importance and imperative of optimism see (Cohen 1929, pp. 20-21) and (Jonas 1987, p. 75).

Quoted in: (Lederberg and Gerstenfeld 2002,n. p.). I thank Yemima Hadad for this reference.

Cf. Martin Buber, "Gemeinschaft und Umwelt. Aufzeichnung für das Vorwort zu E. A. Gutkind, Community and Environment", in (Buber 1966, p. 82). The phrase "Außenglied einer Maschine" is, actually, Gutkind's. Buber's interest in architecture is also documented in his preface to Bruno Zevi's Saper Vedere l'Architettura (1948), which has been analyzed by (Loach and Rapoport 2000).

92 (Fromm 1968, p. 69). Fromm quotes here from Marx's Economical and Philosophical Manuscripts, which he edited. See (Fromm 1961, p. 132). 
(Fromm 1968, p. 89). This included the transformation from "passive consumer to participant society" (p. 114).

Martin Buber, “Das echte Gespräch und die Möglichkeiten des Friedens”, in (Buber 1966, p. 222).

(Buber 1966, p. 119). Buber invokes Étienne de La Boétie, Von der freiwilligen Knechtschaft des Menschen (1574), which Gustav Landauer had translated into German.

Cf. Martin Buber, “Weltraumfahrt. Antwort auf eine Rundfrage” (1957), in (Buber 1966, p. 252).

\section{References}

Adorno, Theodor. 1966. Negative Dialektik. Frankfurt: Suhrkamp.

Albert, Karl. 1994. Philosophie im Schatten von Auschwitz. Dettelbach: J. H. Röll.

Anders, Günther. 1968. Die Antiquiertheit des Menschen. Über die Seele im Zeitalter der zweiten industriellen Revolution. Munich: C. H. Beck. Arendt, Hannah. 1994. Eichmann in Jerusalem: A Report on the Banality of Evil. New York: Penguin Books.

Arendt, Hannah. 1998. The Human Condition. Chicago and London: University of Chicago Press.

Arnold, Matthew. 1994. Culture and Anarchy. New Haven and London: Yale University Press.

Ascher, Saul. 1801. Philosophische Skizzen zur natürlichen Geschichte des Ursprungs, Fortschritts und Verfalls der gesellschaftlichen Verfassungen. Berlin: n. p.

Babich, Babette. 1995. The Poetic Construction of Nature: Hölderlin's Contribution to an Ethos of Nature and Art. Soundings: An Interdisciplinary Journal 78: 263-77.

Baker, Thomas. 1857. The Steam Engine or The Powers of Flame. An Original Poem in Ten Cantos. London: J. S. Hodson.

Balogh, Zoltán. 1969. Martin Buber und die Welt des Es (Beiheifte zur Zeitschrift für philosophische Forschung 20). Meisenheim am Glan: Anton Hain.

Benso, Silvia. 2000. The Face of Things: A Different Side of Ethics. Albany: State University of New York Press.

Bie, Oskar. 1908. Das Kunstgewerbe (Die Gesellschaft 20). Frankfurt: Rütten \& Loening.

Birnbaum, Nathan. 1913. Das Erwachen der jüdischen Seele. In Vom Judentum. Ein Sammelbuch herausgegeben vom Verein jüdischer Hochschüler Bar Kochba. Leipzig: Kurt Wolff.

Bloch, Ernst. 1965. Verfremdungen. Vol. 2: Geographica. Frankfurt/M.: Suhrkam.

Bloch, Jochanan. 1968. Geheimnis und Schöpfung: Elemente der Dialogik Martin Bubers. Berlin: Freie Universität.

Boos, Sonja. 2014. Speaking the Unspeakable in Postwar Germany. Cornell: Cornell University Press.

Braun, Hans-Joachim. 1992. Krieg der Ingenieure: Das mechanisierte Schlachtfeld. In Energiewirtschaft, Automatisierung, Information. Edited by Hans-Joachim Braun and Walter Kaiser. Frankfurt/M.: Propyläen.

Breslauer, S. Daniel. 2019. Martin Buber's Myth of Zion. Newcastle: Cambridge Scholars Publishing.

Brod, Max. 1920. Sozialismus im Zionismus. Vienna and Berlin: Löwit.

Buber, Martin. 2019a. Schriften über das dialogische Prinzip. Martin Buber Werkausgabe 4. Edited by Paul Mendes-Flohr. Gütersloh: Güthersloher Verlagshaus.

Buber, Martin. 2019b. Schriften zur politischen Philosophie und zur Sozialphilosophie. Teilband 1: 1906-1938. Martin Buber Werkausgabe 11.1. Edited by Stefano Franchini. Gütersloh: Güthersloher Verlagshaus.

Buber, Martin. 2019c. Schriften zur politischen Philosophie und zur Sozialphilosophie. Teilband 2: 1938-1965. Martin Buber Werkausgabe 11.2. Edited by Massimiliano De Villa. Gütersloh: Güthersloher Verlagshaus.

Buber, Martin. 1957. Eclipse of God: Studies in the Relation Between Religion and Philosophy. New York: Harper.

Buber, Martin. 1958a. Hasidism and Modern Man. Translated by Maurice Friedman. New York: Horizon Press.

Buber, Martin. 1958b. Paths in Utopia. Translated by Richard Francis Carrington Hull. Boston: Beacon Press.

Buber, Martin. 1960. The Origin and Meaning of Hasidism. Translated by Maurice Friedman. New York: Horizon Press.

Buber, Martin. 1965. The Knowledge of Man. Translated by Maurice Friedman, and Ronald Gregor Smith. London: Gregor Allen \& Unwin.

Buber, Martin. 1966. Nachlese. Heidelberg: Lambert Schneider.

Buber, Martin. 1967. A Believing Humanism: My Testament, 1902-1965. Edited by Ruth Nanda Anshen. New York: Simon and Schuster.

Buber, Martin. 1985. Pfade in Utopia. Über Gemeinschaft und deren Verwirklichung. Heidelberg: Lambert Schneider.

Buber, Martin. 1995. I and Thou. Translated by Walter Kaufmann. New York: Simon \& Schuster.

Buber, Martin. 2001. Frühe kulturkritische und philosophische Schriften, 1891-1924. Martin Buber Werkausgabe 1. Edited by Martin Treml. Gütersloh: Güthersloher Verlagshaus.

Buber, Martin. 2003. Sprachphilosophische Schriften. Martin Buber Werkausgabe 6. Edited by Asher Biemann. Gütersloh: Güthersloher Verlagshaus.

Buber, Martin. 2005. Schriften zu Jugend, Erziehung und Bildung. Martin Buber Werkausgabe 8. Edited by Juliane Jacobi. Gütersloh: Güthersloher Verlagshaus.

Buber, Martin. 2012. Ekstatische Konfessionen. Martin Buber Werkausgabe 2.2. Edited by David Groiser. Gütersloh: Güthersloher Verlagshaus.

Buber, Martin. 2013. Mythos und Mystik: Frühe religionswissenschaftlichen Schriften. Martin Buber Werkausgabe 2.1. Edited by David Groiser. Gütersloh: Güthersloher Verlagshaus.

Buber, Martin. 2016. Chassidismus II: Theoretische Schriften. Martin Buber Werkausgabe 17. Edited by Susanne Talabardon. Gütersloh: Güthersloher Verlagshaus. 
Buber, Martin. 2017. Schriften zu Philosophie und Religion. Martin Buber Werkausgabe 12. Edited by Ashraf Noor. Gütersloh: Güthersloher Verlagshaus.

Buber, Martin. 2018a. Chassidismus I: Frühe Erzählungen. Martin Buber Werkausgabe 16. Edited by Ran HaCohen and Bernd Witte. Gütersloh: Güthersloher Verlagshaus.

Buber, Martin. 2018b. Schriften zum Judentum. Martin Buber Werkausgabe 20. Edited by Michael Fishbane and Paul Mendes-Flohr. Gütersloh: Güthersloher Verlagshaus.

Bücher, Karl. 1896. Arbeit und Rhythmus. Leipzig: S. Hirzel.

Butler, Samuel. 1880. Erewhon or Over the Range. London: David Bogue.

Campbell, John. 1989. Joy in Work, German Work: The National Debate, 1800-1945. Princeton: Princeton University Press.

Cassirer, Ernst. 1961. The Logic of the Humanities. Translated by Clarence Smith Howe. New Haven: Yale University Press.

Cassirer, Ernst. 1985. Symbol, Technik, Sprache. Aufsätze aus den Jahren 1927-1933. Edited by Ernst Wolgang Orth and John Michael Krois. Hamburg: Felix Meiner.

Cassirer, Ernst. 2011. Logik der Kulturwissenschaften. Hamburg: Felix Meiner.

Cohen, Hermann. 1929. Religion der Vernunft aus den Quellen des Judentums. Frankfurt/M.: J. Kauffmann.

Coudenhove-Kalergi, Richard. 1922. Apologie der Technik. Leipzig: Verlag Der Neue Geist.

Coudenhove-Kalergi, Richard. 1958. Eine Idee erobert Europa: Meine Lebenserinnerungen. Vienna: Kurt Desch.

Crowell, Steven. 2018. The Challenge of Heidegger's Approach to Technology: A Phenomenological Reading. In Heidegger on Technology. Edited by Aaron James Wendland, Christopher Merwin and Christos Hadjioannou. New York: Routledge.

Dahlstrom, Daniel O. 2018. Im-Position: Heidegger's Analysis of the Essence of Modern Technology. In Heidegger on Technology. Edited by Aaron James Wendland, Christopher Merwin and Christos Hadjioannou. New York: Routledge.

de Man, Hendrick. 1927. Kampf um die Arbeitsfreude. Leipzig: Diederichs.

Dessauer, Friedrich. 1928. Philosophie der Technik: Das Problem der Realisierung. Bonn: F. Cohen.

Dessauer, Friedrich. 1956. Streit um die Technik. Frankfurt/M.: J. Knecht.

Dipper, Christof. 2017. Ein vergessener Technikphilosoph: Julius Goldstein und die Darmstädter Modernediskurse um 1900. Technikgeschichte 84: 3-27. [CrossRef]

Fichte, Johann Gottlieb. 1923. Reden an die deutsche Nation. Stuttgart: Strecker und Schröder.

Flusser, Vilém. 1993. Dinge und Undinge: Phänomenologische Skizzen. Munich: Carl Hanser.

Forster, Edward Morgan. 2009. The Machine Stops. In Technology and Society: Building our Sociotechnical Future. Edited by Deborah G. Johnson and Jameson M. Wetmore. Cambridge and London: MIT Press.

Fromm, Erich. 1961. Marx's Concept of Man. New York: Ungar.

Fromm, Erich. 1968. The Revolution of Hope: Toward a Humanized Technology. New York: Harper \& Row.

Furness, Raymond. 2000. Zarathustra's Children: A Study of a Lost Generation of German Writers. Rochester: Camden House.

Gans, Eduard. 2005. Naturrecht und Universalgeschichte. Vorlesungen nach G. W. F. Hegel. Edited by Johann Bauer. Tübingen: Mohr Siebeck.

Gillman, Abigail. 2014. "Seit ein Gespräch wir sind und hören können voneinander": Martin Buber's Message to Postwar Germany. Nexus: Essays in German Jewish Studies 2: 121-51.

Gittleman, Sol. 1979. Fritz Lang's "Metropolis" and Georg Kaiser's "Gas I": Film, Literature, and the Crisis of Technology. Die Unterrichtspraxis/Teaching German 12: 27-30. [CrossRef]

Goethe, Johann Wolfgang. 1977. Wilhelm Meisters Wanderjahre. In Sämtliche Werke 8. Edited by Ernst Beutler. Zurich: Artemis.

Goldstein, Julius. 1909. Soziologie der Technik. Internationale Wochenschrift für Wissenschaft und Technik 2: 807-21.

Goldstein, Julius. 1911. Ethische Probleme der Technik. Stahl und Eisen 31: 355-57.

Goldstein, Julius. 1912. Die Technik. Frankfurt: Rütten \& Loening.

Gordon, Aaron David. 1929. Erlösung durch Arbeit. Ausgewählte Aufsätze. Translated by Viktor Kellner. Berlin: Jüdischer Verlag.

Gordon, Aaron David. 2020. Man and Nature: Meditations and Dreams of a Radical. Edited by Yuval Jobani and Ron Margolin. Jerusalem: Magnes [Hebrew].

Grigenti, Fabio. 2016. Existence and Machine: The German Philosophy in the Age of Machines (1870-1960). New York: Springer.

Habermas, Jürgen. 2003. The Future of Human Nature. Cambridge: Polity Press.

Hadad, Yemima. 2018. Fruits of Forgetfulness: Politics and Nationalism in the Philosophies of Martin Buber and Martin Heidegger. In Heidegger and Jewish Thought: Difficult Others. Edited by Elad Lapidot and Micha Brumlik. Lanham: Rowman \& Littlefield.

Haffter, Isabelle. 2021. Politik der Glückskulturen: NS-Deutschland und die Schweiz, 1933-1945. Berlin: deGruyter.

Heidegger, Martin. 1962a. Being and Time. Translated by John Macquarrie, and Edward Robinson. New York: Harper \& Row.

Heidegger, Martin. 1962b. Die Frage nach dem Ding. Zu Kants Lehre von den transzendentalen Grundsätzen. Tübingen: Max Niemeyer.

Heidegger, Martin. 1966. Discourse on Thinking: A Translation of Gelassenheit by John Anderson and E. Hans Freund. New York: Harper \& Row.

Heidegger, Martin. 1977. The Question Concerning Technology and Other Essays. Translated by William Lovitt. New York: Harper Perennial.

Heidegger, Martin. 1978. Vorträge und Aufsätze. Pfullingen: Neske.

Heidegger, Martin. 2001. Sein und Zeit. Tübingen: Max Niemeyer.

Heidegger, Martin. 2013. Wegmarken. Frankfurt/M.: Klostermann. 
Herder, Johann Gottfried. 1784. Ideen zur Philosophie der Geschichte der Menschheit. In Herders Werke III. Edited by Heinrich Kurz. Leipzig: Bibliographisches Institut, n.d.

Herf, Jeffrey. 1981. Reactionary Modernism: Some Ideological Origins of the Primacy of Politics in the Third Reich. Theory and Society 10.6: 805-32. [CrossRef]

Herf, Jeffrey. 1986. Reactionary Modernism: Technology, Culture, and Politics in Weimar and the Third Reich. Cambridge: Cambridge University Press.

Herzl, Theodor. 1934. Gesammelte Zionistische Schriften 1. Tel Aviv: Hozaah Ivrith.

Hoffmann, Walther. 1913. Neue Mystik. In Die Religion in Geschichte und Gegenwart. Edited by Friedrich Michael Schiele and Leopold Scharnack. Tübingen: Mohr, vol. 1.

Horrox, James. 2009. A Living Revolution: Anarchism in the Kibbutz Movement. Oakland: AK Press.

Horwitz, Rivka. 1988. Buber's Way to "I and Thou": The Development of Martin Buber's Thought and his "Religion as Presence" Lectures. Philadelphia: JPS.

Hotam, Yotam. 2013. Modern Gnosis and Zionism: The Crisis of Culture, Life Philosophy, and Jewish National Thought. New York: Routledge. Jaspers, Karl. 1949. Vom Ursprung und Ziel der Geschichte. Munich: Piper.

Jaspers, Karl. 1958. Die Atombombe und die Zukunft des Menschen. Politisches Bewußtsein in unserer Zeit. Munich: Piper.

Jaspers, Karl. 1979. Die geistige Situation der Gegenwart. Berlin: Walter de Gruyter.

Jonas, Hans. 1987. Technik, Medizin, und Ethik. Praxis des Verantwortung. Frankfurt/M.: Suhrkamp.

Joronen, Mikko. 2015. Heidegger on the History of Machination: Oblivion of Being as Degradation of Wonder. Critical Horizons: A Journal of Philosophy and Social Theory 13: 351-76. [CrossRef]

Jünger, Ernst. 1931. Die totale Mobilmachung. Berlin: Junker \& Dünnhaupt.

Jünger, Ernst. 1981. Sämtliche Werke 8. Zweite Abteilung: Essays II. Stuttgart: Klett Cotta.

Jünger, Friedrich Georg. 1928. Aufmarsch des Nationalismus. Berlin: Vormarsch Verlag.

Kapp, Ernst. 1877. Grundlinien einer Philosophie der Technik. Zur Entstehungsgeschichte der Cultur aus neuen Gesichtspunkten. Braunschweig: George Westermann.

Klages, Ludwig. 1920. Mensch und Erde. Munich: Georg Müller.

Klein, Rony. 2020. Heidegger, Hölderlin und die Technik: Verwindung der Metaphysik mit Blick auf deren griechischen Ursprung. In Made in Germany: Technologie, Geschichte, Kultur. Edited by Shaul Katzir, Sagi Schaefer and Galili Shahar. Göttingen: Wallstein Verlag.

Kohn, Hans. 1979. Martin Buber. Sein Werk und seine Zeit. Ein Beitrag zur Geistesgeschichte Mitteleuropas 1880-1930. Wiesbaden: Fourier.

Krantz, Susan F. 2002. Refuting Peter Singer's Ethical Theory: The Importance of Human Dignity. Westport: Greenwood Publishing.

Lahav, Hagar. 2014. Postsecular Jewish Theology: Reading Gordon and Buber. Israel Studies 19: 189-213. [CrossRef]

Landauer, Gustav. 1901. Durch Absonderung zur Gemeinschaft. In Das Reich der Erfüllung (Flugschriften zur Begründung einer neuen Weltanschauung, 1.2). Edited by Heinrich und Julius Hart. Leipzig: Diederichs.

Landauer, Gustav. 2017. Aufruf zum Sozialismus. Berlin: Holzinger.

Lapidot, Elad. 2020. Is Technology Jewish? A Conversation With Martin Heidegger. Journal of Jewish Thought E Philosophy 28: 95-120.

Lebovic, Nitzan. 2013. The Philosophy of Life and Death: Ludwig Klages and the Rise of a Nazi Biopolitics. New York: Palgrave.

Lederberg, Natanel, and Manfred Gerstenfeld. 2002. Nature and the Environment in Hasidic Sources. In Jewish Environmental Perspectives. No. 5 (October 1). Jerusalem: Jerusalem Center for Public Affairs.

Lessing, Theodor. 1930. Europa und Asien: Untergang der Erde am Geist. Leipzig: Felix Meiner.

Lessing, Theodor. 1981. Die Verfluchte Kultur: Gedanken über den Gegensatz von Leben und Geist. Munich: Matthes \& Seitz.

Lieber, Hans-Joachim. 1974. Kulturkritik und Lebensphilosophie: Studien zur deutschen Philosophie der Jahrhundertwende. Darmstadt: Wissenschaftliche Buchgesellschaft.

Lingis, Alphonso. 1998. The Imperative. Bloomington: Indiana University Press.

Loach, Judy, and Raquel Rapoport. 2000. Buber on (looking at) Architecture. Journal of Architecture 5: 189-214. [CrossRef]

Löwy, Michael. 2018. Martin Buber's Socialism. In Martin Buber: His Intellectual and Scholarly Legacy. Edited by Sam Berrin Shonkoff. Leiden and Boston: Brill.

Mendes-Flohr, Paul, and Bernard Susser. 1976. Alte und neue Gemeinschaft: An unpublished Buber Manuscript. AJS Review 1: 41-56.

Mendes-Flohr, Paul. 1976. Werner Sombart's: The Jews and Modern Capitalism-An Analysis of its Ideological Premises. Leo Baeck Institute Yearbook XXI: 87-107. [CrossRef]

Mendes-Flohr, Paul. 1978. Von der Mystik zum Dialog: Martin Bubers Geistige Entwicklung bis hin zu "Ich und Du". Translated by Dafna Kries. Königstein: Jüdischer Verlag.

Mendes-Flohr, Paul. 2001. Zarathustra as a Prophet of Jewish Renewal: Nietzsche and the Young Martin Buber. Revista Portuguesa de Filosofia 57: 103-11.

Mendes-Flohr, Paul. 2006. The Desert Within and Social Renewal-Martin Buber's Vision of Utopia. In New Perspectives on Martin Buber. Edited by Michael Zank. Tübingen: J. C. B. Mohr Siebeck.

Mendes-Flohr, Paul. 2014. Martin Buber and Martin Heidegger in Dialogue. Journal of Religion 94: 2-25. [CrossRef]

Meyer, Ahlrich. 1969. Mechanische und organische Metaphorik politischer Philosophie. Archiv für Begriffsgeschichte 13: 128-99.

Meyer, Michael. 1999. The Thought of Leo Baeck: A Religious Philosophy for a Time of Adversity. Modern Judaism 19: 107-17. [CrossRef] 
Michel, Ernst. 1960. Sozialgeschichte der Industriellen Arbeitswelt: Ihre Krisenformen und Gestaltungsversuche. Frankfurt/M.: J. Knecht.

Milani, Tommaso. 2020. Hendrick de Man and Social Democracy: The Idea of Planning in Western Europe, 1914-1940. New York: Palgrave.

Mitcham, Carl. 1994. Thinking Through Technology: The Path Between Engineering and Philosophy. Chicago and London: University of Chicago Press.

Morat, Daniel. 2007. Von der Tat zur Gelassenheit: Konservatives Denken bei Martin Heidegger, Ernst Jünger und Friedrich Georg Jünger, 1920-1960. Göttingen: Wallstein.

More, Max, and Natasha Vita-More, eds. 2013. The Transhumanist Reader: Classical and Comparative Essays on the Science, Technology and Philosophy of the Human Future. Oxford: Wiley-Blackwell.

Müller, Jan-Werner. 2002. The Soul in the Age of Society and Technology: Helmuth Plessner's Defensive Liberalism. In Confronting Mass Democracy and Industrial Technology: Political and Social Theory From Nietzsche to Habermas. Edited by John P. McCormick. Durham and London: Duke University Press.

Mumford, Lewis. 1970. The Myth of the Machine: The Pentagon of Power. New York: Harcourt, Brace, Jovanovich.

Muth, Cornelia. 2020. Technik aus dialogphilosophischer Sicht: Keine Technik aber ein Gespräch! In Pädagogische Anthropologie der Technik: Praktiken, Gegenstände und Lebensformen. Edited by Johannes Bilstein, Matthias Winzen and Jörg Zirfas. Wiesbaden: Springer.

Nelson, Eric S. 2014. Technology and the Way: Buber, Heidegger, and Lao-Zhuang "Daoism”. Journal of Chinese Philosophy 41: 307-27. [CrossRef]

Novak, David. 1985. Buber's Critique of Heidegger. Modern Judaism 5: 125-40. [CrossRef]

Oldemeyer, Ernst. 2007. Leben und Technik: Lebensphilosophische Positionen von Nietzsche zu Plessner. Munich: W. Fink.

Penslar, Derek. 1991. Zionism and Technocracy: The Engineering of the Jewish Settlement in Palestine, 1870-1918. Bloomington: Indiana University Press.

Picard, Max. 1929. Das Menschengesicht. Munich: Delphin Verlag.

Picard, Max. 1960. Wo steht heute der Mensch? In Wo stehen wir heute? Edited by Walter Bähr. Gütersloh: Bertelsmann.

Plessner, Helmuth. 1985. Die Utopie in der Maschine. In Gesammelte Schriften 10: Schriften zur Soziologie und Sozialphilosophie. Edited by Günter Dux, Odo Marquart and Elisabeth Ströker. Frankfurt/M.: Suhrkamp.

Rabinbach, Anson. 1992. The Human Motor: Energy, Fatigue, and the Origins of Modernity. Berkeley: University of California Press.

Rathenau, Walther. 1918. Von kommenden Dingen. Berlin: S. Fischer.

Rathenau, Walther. 1919. Zur Kritik der Zeit. Berlin: S. Fischer.

Riedel, Manfred. 1967. Hegel und Gans. In Natur und Geschichte: Karl Löwith zum 70. Geburtstag. Edited by Herman Baum and Manfred Riedel. Stuttgart: Kohlhammer.

Rome, Sidney, and Beatrice Rome, eds. 1964. Philosophical Interrogations. New York: Holt, Rinehart, Winston.

Rosenstock-Huessy, Eugen. 1955. Der Unbezahlbare Mensch. Berlin: Käthe Vogt.

Rousseau, Jean-Jacques. 1973. The Social Contract and Discourses. Translated by George Douglas Howard Cole. London: J. M. Dent \& Sons.

Sallis, John. 1983. End(s). Research in Phenomenology 13: 85-96. [CrossRef]

Santmire, H. Paul. 1968. I-Thou, I-It, and I-Ens. Journal of Religion 48: 260-73. [CrossRef]

Schilpp, Paul Arthur, and Maurice Friedman, eds. 1967. The Philosophy of Martin Buber. La Salle and London: Cambridge University Press.

Schweid, Eliezer. 1983. Martin Buber und Aharon David Gordon-Eine Gegenüberstellung. In Martin Buber: Bilanz seines Denkens. Edited by Jochanan Bloch and Haim Gordon. Freiburg: Herder.

Singer, Peter, and Agata Sagan. 2016. Rights for Robots? In Ethics in the Real World: 82 Brief Essays on Things That Matter. Princeton: Princeton University Press.

Sombart, Werner. 1911. Technik und Kultur. In Verhandlungen des Ersten Deutschen Soziologentages. Tübingen: J. C. B. Mohr.

Spengler, Oswald. 1931. Der Mensch und die Technik. Munich: C. H. Beck.

Spengler, Oswald. 1980. Der Untergang des Abendlandes: Umriss einer Morphologue der Weltgeschichte. Stuttgart: Deutscher Bücherbund. Spörl, Uwe. 1997. Gottlose Mystik in der Deutschen Literatur um die Jahrhundertwende. Paderborn: Schöningh.

Stegmaier, Werner, and Daniel Krochmalnik, eds. 1997. Jüdischer Nietzscheanismus. Berlin: De Gruyter.

Steinbock, Anthony. 2015. Heidegger, Machination, and the Jewish Question: The Problem of the Gift. Journal of Cultural and Religious Theory 15: 72-89. [CrossRef]

Stern, Fritz. 1965. The Politics of Cultural Despair: A Study in the Rise of Germanic Ideology. New York: Anchor Books.

Stollberg-Rilinger, Barbara. 1986. Der Staat als Maschine: Zur politischen Metaphorik des absoluten Fürstenstaates. Berlin: Duncker \& Humblot.

Susser, Bernard. 1979. The Anarcho-Federalism of Martin Buber. Publius 9: 103-15. [CrossRef]

Susser, Bernard. 1981. Existence and Utopia: The Social and Political Thought of Martin Buber. London and Toronto: Associated University Presses.

Thoreau, Henry David. 2014. On the Duty of Civil Disobedience. In Walden and On the Duty of Civil Disobedience. Minneapolis: Lerner Publishing.

Tirosh-Samuelson, Hava. 2012. Transhumanism as a Secular Faith. Zygon 47: 710-34. [CrossRef] 
Tirosh-Samuelson, Hava. 2017a. Jewish Environmental Ethics: The Imperative of Responsibility. In The Wiley Blackwell Companion to Religion and Ecology. Edited by John Hart. Hoboken, NJ: Wiley Blackwell.

Tirosh-Samuelson, Hava. 2017b. Religion, Science, and Technology in the Post-Secular Age: The Case of Trans/Posthumanism. Philosophy, Theology, and the Sciences 4: 7-45. [CrossRef]

Toller, Ernst. 1922. Die Maschinenstürmer: Ein Drama aus der Zeit der Ludditenbewegung in England in fünf Akten und einem Vorspiel. Leipzig: Tal \& Co.

Tönnies, Ferdinand. 1963. Community and Society. Translated by Charles P. Loomis. New York: Harper \& Row.

Viereck, Peter. 1949. The Poet in the Machine Age. Journal of the History of Ideas 10: 88-103. [CrossRef]

Vogt, Stefan. 2015. Between Decay and Doom: Zionist Discourses of 'Untergang' in Germany, 1890 to 1933. In The German-Jewish Experience Revisited. Edited by Steven Aschheim and Vivian Liska. Berlin and New York: De Gruyter.

Voigt, Manfred. 2003. "Wir Sollen Alle Kleine Fichtes Werden": Johann Gottlieb Fichte als Prophet der Kulturzionisten. Berlin und Wien: Philo-Verlag.

Weiss, Ales. 2017. Buddhism as a Tool of Polemic and Self-Definition among German Rabbis in the 19th and 20th Century. Pardes: Zeitschrift der Vereinigung Jüdischer Studien 23: 73-93.

Wrathall, Mark A. 2018. The Task of Thinking in a Technological Age. In Heidegger on Technology. Edited by Aaron James Wendland, Christopher Merwin and Christos Hadjioannou. New York: Routledge.

Zuber, Uwe. 2008. Julius Goldstein: Der Jüdische Philosoph in Seinen Tagebüchern, 1873-1929: Hamburg, Jena, Darmstadt. Wiesbaden: Schriften der Kommission für die Geschichte der Juden in Hessen. 